\title{
Matematik ve Fen Başarısının Belirleyicisi Olarak Öğretmenlerin Eğitim Düzeyi
}

\section{Teachers' Education Level as a Predictor for Mathematics and Science Achievement}

\author{
Umut Birkan Özkan ${ }^{\mathrm{a}^{*}}$ \\ ${ }^{a}$ Dr.Öğr. Üyesi, Milli Savunma Üniversitesi, Kara Astsubay MYO, Eğitim Bilimleri Bölümü, 10100, Balıkesir/Türkiye. \\ ORCID: 0000-0001-8978-3213
}

\section{MAKALE BİLGİSI}

\section{Makale Geçmişi:}

Başvuru tarihi: 04 Şubat 2019

Düzeltme tarihi: 30 Mart 2019

Kabul tarihi: 12 Nisan 2019

\section{Anahtar Kelimeler:}

Akademik Başarı

Fen Başarısı

Matematik Başarısı

Öğretmenlerin Eğitim Düzeyi

TIMSS
ÖZ

Öğretmenlerin eğitim düzeyinin, öğretmen kalitesinin ve öğrenci performansının belirleyicileri arasında yer aldığı söylenebilir. Bu araştırma, TIMSS-2015'te birinci ve sonuncu sıradaki ülkeler ile Türkiye'deki matematik ve fen öğretmenlerinin eğitim düzeylerinin, sekizinci sınıf öğrencilerinin matematik ve fen başarısı üzerindeki belirleyiciliğini incelemek amacıyla ilişsisel tarama deseni kullanılarak gerçekleştirilmiştir. Araştırmanın evreni, TIMSS-2015'e Güney Afrika, Singapur, Suudi Arabistan ve Türkiye'den katılan öğrencilerdir. Evrenin tamamına ulaşıldığından örneklem tayinine gidilmemiştir. Veriler, IEA'nın veri tabanında yer alan öğretmen ve öğrenci anketlerinden elde edilmiştir. Verilerin analizinde çoklu doğrusal regresyon analizi kullanılmıştır. Araştırmanın sonucunda, öğretmenlerin eğitim düzeylerinin Singapurlu, Türk ve Güney Afrikalı öğrencilerin fen başarısında, Singapurlu ve Suudi öğrencilerin ise matematik başarısında istatistiksel olarak anlamlı bir belirleyici olmadığı, Türk öğrencilerin matematik başarısı için önem düzeyi düşük bir belirleyici olduğu saptanmıştır.

\section{ARTICLE INFO}

\section{Article history:}

Received 04 February 2019

Received in revised form 30 March 2019

Accepted 12 April 2019

\section{Keywords:}

Academic Achievement

Science Achievement

Mathematics Achievement

Education Level of Teachers

TIMSS

\begin{abstract}
A B S T R A C T
This study aims to investigate the effect of educational levels of mathematics and science teachers on the academic achievement of 8th grade students in mathematics and science using TIMSS-2015 data of Turkey, first ranked country and latest ranked country. In this study, correlational design was used. The study population is consisted of South Africa, Singapore, Saudi Arabia 8th grade students who participated in the TIMSS-2015. As the entire population was reached, sampling methods was not used. The data were obtained from the teacher and student questionnaires included in the database provided by IEA for open access. Multiple linear regression was used to analyze the data. As a result of the research, it can be argued that the educational level of teachers is not a statistically significant variable for science achievement of the students of Singapore, Turkey and South Africa, and for mathematics achievement of Singaporean and Saudi students.
\end{abstract}

\section{Giriș}

Öğretmen nitelikleri, öğretmen kalitesinin ve öğrenci performansının belirleyicileri arasında yer alan kişiye özgü ve mesleki özellikler şeklinde tanımlanabilir (Jepsen, 2005; Lai, Sadoulet ve De Janvry, 2011; Oktay, 1991). Öğretmen niteliklerinin eğitim sisteminin verimliliği, okul iklimi, öğrenci memnuniyeti, öğrenci becerileri ve öğrencilerin akademik başarısı gibi değişkenleri etkileyen öğelerden biri olduğu söylenebilir (Aslam ve diğerleri, 2016; BratschHines ve diğerleri, 2017; Connor ve diğerleri, 2005; DeAngelis ve Presley, 2011; Ingersoll, 2007; Karakelle, 2005). Bu değişkenlerden biri olan öğrenci başarısına

\footnotetext{
* Sorumlu yazar/Corresponding author

e-posta: umutbirkanozkan@gmail.com
} 
öğretmen niteliklerinin yaptığı etkilerin, araştırmacıların dikkatini çeken konular arasında olduğu görülmektedir (Aliyu, Yashe ve Adeyeye, 2013; Buddin ve Zamarro, 2009; Ehrenberg ve Brewer, 1994; Lai ve diğerleri, 2011; Muriithi, 2018; Oduh ve Okanigbuan, 2014; Richardson, 2008). Örneğin; Richardson'ın (2008) elde ettiği bulgular, öğretmen nitelikleri ile öğrenci başarısı arasında anlamlı bir ilişki olduğunu göstermektedir. Buddin ve Zamarro (2009) da yaptıkları çalışmada, bazı öğretmen niteliklerinin öğrencilerin akademik başarısında kilit unsurlar olduğuna dikkat çekmektedir. Ehrenberg ve Brewer (1994) ise öğretmen niteliklerinin öğrencilerin test puanlarını etkileyebildiğini ve bu nedenle öğretmen niteliklerinin öğrencilerin test puanlarına olan etkisinin analiz edilmesi gerektiğini vurgulamaktadır. $\mathrm{Bu}$ konuda yapilan çalışmalarda öğretmenlerin deneyimleri, eğitim düzeyleri, mesleğe karşı tutumları, mesleki sertifikalara sahip olmaları gibi değişkenlerin öğrenci başarısına etki eden öğretmen niteliklerinden olduğu belirtilmektedir (Dodeen ve diğerleri, 2012; Maphoso ve Mahlo, 2015; Musau ve Abere, 2015; Ojera, 2016; Subedi, Reese ve Powell, 2015).

$\mathrm{Bu}$ çalışmada ise öğretmen niteliklerinden birisi olan öğretmenlerin eğitim düzeyinin (Coleman ve diğerleri, 1966), öğrenci başarısına etkisi üzerine odaklanılmaktadır. Öğretmenlerin eğitim düzeyleri ile öğrenci başarıları arasındaki ilişkiyi inceleyen araştırmalar çok yönlü sonuçlar sunmaktadır. Bazı araştırmacılar, öğretmenlerin eğitim düzeyinin, öğrenci performansını olumlu yönde etkileyen güçlü bir faktör olduğunu savunmaktadır (Athar ve Jamal, 2017; Darling-Hammond, 2000; Goldhaber ve Brewer, 1996,1997,1998; Subedi ve diğerleri, 2015; Vandersall, Vruwink ve LaVenia, 2011). DarlingHammond'ın (2000) araştırması, donanımlı öğretmenlerin öğrenci başarısı üzerindeki etkilerinin yoksulluk, dil bilgisi ve azınlık statüsü de dahil olmak üzere öğrencinin arka plan etkenlerinden daha ağır basabileceğini göstermiştir. $\mathrm{Bu}$ araştırmaya göre, öğretmen niteliği olarak eğitim seviyesi (yüksek lisans derecesine sahip olma), öğrenci puanlarını içeren eğitimsel sonuçlarla pozitif yönde fakat çok da güçlü olmayan bir ilişki göstermektedir. Amerika Birleşik Devletleri'nin Georgia eyaleti genelindeki eğitim kalitesini ölçmek için kullanılan Ölçüt Referanslı Yeterlilik Testleri (Criterion-Referenced Competency Tests [CRCT]) sonuçlarına dayalı olarak Vandersall ve diğerlerinin (2011) gerçekleştirdiği çalışmada, öğrencilerin okuma becerileri ve anadil dersindeki başarıları üzerinde öğretmenlerin eğitim düzeyinin etkisi incelenmiştir. Bu çalışmada, öğretmenleri yüksek lisans yapmış olan öğrencilerin hem okuma becerileri hem de anadil (İngilizce) dersinde, öğretmenleri yüksek lisans yapmamış öğrencilere göre istatistiksel olarak anlamlı derecede daha iyi performans sergiledikleri görülmüştür. Athar ve Jamal'ın (2017), 8. sınıf öğrencilerine ait verilerle gerçekleştirdiği çalışmada, lisans ve yüksek lisans mezunu öğretmenlerin öğrencilerinin akademik başarıları arasında anlamlı bir farklılık olduğu bulunmuştur. İngilizce ve matematik testinin uygulandığ bu çalışmada, yüksek lisans derecesine sahip öğretmenlerin öğrencilerinin diğerlerine göre daha başarılı oldukları ve lisansüstü eğitimin, öğrencilerin daha iyi bir akademik başarı elde etmeleri için öğretmen yetkinliğini arttırdı ̆̆ sonucuna varılmıştır. Goldhaber ve Brewer (1996,1997), öğretmenlerin yüksek lisans derecelerinin lise öğrencilerinin matematik ve fen başarısındaki etkilerini değerlendirmek için, Ulusal Eğitim Boylamsal Çalışması1988 (National Educational Longitudinal Study 1988 [NELS:88]) verilerine dayanarak bir araştırma yapmışlardır. Araştırmacılar, matematikte ve fende öğrenci başarısının, öğretmenlerin matematik ve fen alanında yüksek lisans derecesine sahip olmalarıyla pozitif yönde ilişkili olduğunu bulmuşlardır. Bu çalışmanın bir diğer sonucu ise, öğretmenlerin yüksek lisansı olmadığı veya yüksek lisansını matematik ve fen dışındaki bir konuda yaptığı durumlarda öğrenci başarısı üzerinde hiçbir etkisinin olmadığıdır. Öğrenci not ortalamasında etkisi olan öğretmen kaynaklı faktörlerin araştırıldığı bir başka çalışma ise Subedi ve diğerlerinin (2015) araştırmasıdır. Amerika Birleşik Devletleri'ndeki düşük performans gösteren dört lisede uygulanan Liseden Mezuniyet Girişimi (High School Graduation Initiative [HSGI]) programından elde edilen verilerle yapılan araştırmada, öğretmenlerin eğitim düzeylerinin öğrencilerin not ortalaması üzerinde olumlu etkileri olduğu bulunmuştur. Lisansüstü eğitimi olan öğretmenlerin, öğrencilerin not ortalamasının yükseltilmesi yanında öğrencilerin devamsızlığının düşürülmesinde de önemli bir etkiye sahip olması nedeniyle işe alımlarda yöneticiler tarafından tercih edilebileceği vurgulanmaktadır. Benzer bir görüşü savunan Goldhaber ve Brewer'a (1998) göre matematik ve fen bilimlerinde öğrenci başarısı, bu alanlarda öğretmenlerin lisansüstü eğitimini zorunlu tutmak suretiyle geliştirilebilir.

Alan yazındaki araştırmaların bir kısmında ise öğretmenlerin eğitim düzeyinin öğrencilerin akademik başarısı üzerinde çok sınırlı bir etkisinin olduğu veya hiçbir etkisinin olmadığı yönünde bulgular elde edilmiştir (Badgett, Decman ve Carman, 2013; Coenen ve diğerleri, 2014; Croninger ve diğerleri, 2007; Feng ve Sass, 2013; Ferguson ve Ladd, 1996; Gage ve diğerleri, 2017; Link ve Ratledge, 1979; Nye, Konstantopoulos ve Hedges, 2004; Rowan, Correnti ve Miller, 2002). Link ve Ratledge'1n (1979), 1969-1970 eğitim-öğretim yılında öğrenim gören 500 öğrencinin verilerini kullanıldığ çalışma bunlara örnek verilebilir. $\mathrm{Bu}$ araştırmanın sonuçlarına göre öğretmenin eğitim düzeyi, çalışmanın yapıldığı Wilmington (Amerika Birleşik Devletleri'nin Delaware eyaletine bağlı bir şehir) örneği için, okuma başarısında göreceli olarak önemsiz faktörler arasındadır. Daha yakın tarihli çalışmalarda da benzer sonuçlara rastlanmaktadır. Örneğin, Ferguson ve Ladd (1996) tarafindan yapılan ve Amerika Birleşik Devletleri'nin Alabama eyaletinde bulunan 690 okuldaki 4. sınıf öğrencilerine odaklandıkları çalışmada, yüksek lisans derecesine sahip öğretmenler, öğrencilerin matematik puanları üzerinde küçük bir pozitif etki yaptığı ancak bu durumun okuma puanlarında hiç etki göstermediği sonucuna ulaşılmıştır. Nye ve diğerlerinin (2004) çalışmasında da benzer sonuçlara ulaşılmıştır. Bu çalışmada, Amerika Birleşik Devletleri'nin Tennessee eyaletinde gerçekleştirilen Öğrenci-Öğretmen Başarı Oranı projesinin (Student-Teacher Achievement Ratio, Project STAR) bir parçası olarak, anaokulundan ilkokul 3. sınıfa kadar uygulanan Stanford Başarı Testi (SAT) okuma ve matematik testi puanlarından faydalanılmıştır. Çalışma kapsamında, öğretmenlerin eğitim düzeyinin öğrencilerin başarıları üzerindeki tahmini etkileri 1. ve 2. sınıflarda önemsiz düzeyde bulunmuştur. $\mathrm{Bu}$ çalışmaya göre, öğretmenlerin eğitim düzeyi yalnızca 3. sınıf matematik başarısı için istatistiksel olarak anlamlıdır. Badgett ve 
diğerleri (2013), 2009 y1lında Amerika Birleşik Devletleri'nin Texas eyaleti genelinde uygulanan Texas Matematik Bilgi ve Becerilerinin Değerlendirilmesi (Math Texas Assessment of Knowledge and Skills [TAKS]) testi sonuçlarına göre öğretmenlerin eğitim düzeylerinin öğrencilerin matematik başarısı üzerindeki etkisini incelemişlerdir. Araştırmanın sonuçları, yüksek lisans derecelerinin öğrencinin matematik başarısı üzerinde yalnızca kısıtlı bir olumlu etkisi olduğunu göstermiştir. Croninger ve diğerleri (2007), ilkokul öğrencilerinin okuma ve matematik başarıları ile öğretmen nitelikleri arasındaki ilişkiyi analiz etmek için Erken Çocukluk Boylamsal Çalışmasından (Early Childhood Longitudinal Study [ECLS]) elde ettikleri verileri kullanarak bir çalışma gerçekleştirmişlerdir. $\mathrm{Bu}$ çalışmada, öğretmenlerin lisansüstü dereceye sahip olma ölçütünün, ilkokul öğrencilerinin okumadaki başarısı ile pozitif ilişkisi olmadığı bulunmuştur. Aynı zamanda, öğrencinin matematik başarısı ile lisansüstü eğitime sahip olma arasında negatif bir ilişkinin varlığından söz edilmektedir. Feng ve Sass'ın (2013) çalışmasına göre, lisansüstü eğitimi olan öğretmenler, engelli öğrencilerin matematik başarılarını artırmada lisans derecesine sahip olanlardan daha etkilidir. $\mathrm{Bu}$ çalışmada da, okuma becerileri için lisansüstü dereceye sahip öğretmenler açısından başarı farkı bulunmamıştır. Ayrıca bu çalışmada, öğretmenin lisansüstü eğitiminin olmasının, mesleğin başındaki öğretmenler için öğrenci başarısının artmasıyla ilişkili olduğu bulunsa da tecrübeli öğretmenler için bu durumun geçerli olmadığı yazarlar tarafindan ifade edilmektedir. Coenen ve diğerlerinin (2014), alanyazın taramasına dayalı çalışmasının sonuçlarına göre, öğretmenlerin eğitim düzeyleri, öğrenci test puanları için önemli bir etkiye sahip değildir. Bu çalışmada, yüksek lisans dereceleri gibi ileri dereceler, daha yüksek öğrenci test puanları ile ilişkili bulunmamıştır. Gage ve diğerlerinin (2017) çalışmasından elde edilen bulgular, duygu ve/veya davranış bozukluğu olan öğrencilerde, öğretmenlerin eğitim seviyesinin akademik başarıdaki artış ile ilişkili olmadığını göstermektedir.

Bazı çalışmalarda, Croninger ve diğerlerinin (2007) çalışmasında olduğu gibi öğretmenlerin eğitim düzeyinin artmasının öğrencilerin akademik başarısına negatif etkisi olduğuna ilişkin bulgular göze çarpmaktadır. Rowan ve diğerlerinin (2002), ulusal verileri kullanarak yürüttükleri bir araştırmada, öğretmenlerin eğitim düzeyinin öğrencilerin okuma başarısı üzerinde istatistiksel olarak önemli bir etkiye sahip olmadığı görülmüştür. Bununla birlikte, matematikte yüksek lisans derecesine sahip öğretmenlerin öğrencilerinin, yüksek lisansı olmayan öğretmenlerin öğrencilerine göre daha kötü durumda oldukları da bu çalışmanın bulguları arasındadır.

Yukarıda sunulan alanyazın taramasından elde edilen çok yönlü bulgular sonucunda, öğretmenlerin eğitim düzeyinin öğrenci başarısı üzerinde ilişkisel bağlamda tutarlı bir rolü olmadığı söylenebilir. Diğer bir ifadeyle, öğretmenlerin eğitim düzeyinin öğrencilerin akademik başarısı üzerindeki etkisinin tam olarak açıklanamadığına dair düşünceler oluşabilir. Araştırma konusuna ilişkin alanyazında fikir birliğine varılamamış olmasının yanında, güncel ve yüksek kaliteli veri setlerini kullanan araştırmalara ihtiyaç duyulduğu da ifade edilebilir. Buna ek olarak, birçok öğrenci grubu için öğretmenlerin eğitim düzeyi ve öğrencilerin akademik başarıları arasındaki ilişki incelenmesine rağmen, bu ilişkileri özellikle uluslararası değerlendirmelerde başarılı ve başarısız olmuş ülkelerin öğrencileri için karşılaştırmalı olarak inceleyen araştırmaya rastlanamamaktadır. Özellikle ortaokul öğretmenleri için belirli bir branşta lisansüstü eğitim düzeyinin etkinliği üzerine yapılmış araştırmaların olmadığı görülmektedir. Bugüne kadar yapılan araştırmalar, Türkiye'deki ortaokul öğrencileri için öğretmenlerin eğim düzeyi ile öğrencilerin akademik başarısı arasındaki ilişkinin varlığına dair bilimsel kanıtları ortaya koyamamaktadır.

2015 yılında yapılan Uluslararası Matematik ve Fen Eğilimleri Araştırmasında (Trends in International Mathematics and Science Study, TIMSS) ilk ve son sirayı alan ülkeler ile Türkiye'nin verilerinin kullanıldığı bu çalışmada, matematik ve fen öğretmenlerinin eğitim düzeylerinin sekizinci sınıf öğrencilerinin matematik ve fen alanlarındaki akademik başarısı üzerindeki belirleyiciliğini incelemek amaçlanmıştır. Ancak, akademik başarıyı etkileyen farklı değişkenlerin olması muhtemeldir ve TIMSS-2015'in tüm bu farklı değişkenlerin kontrol altında tutulduğu deneysel çalışma tasarımına sahip olmadığı ifade edilebilir (Yıldırım ve diğerleri, 2013). Bununla birlikte, akademik başarının açıklanması için birden fazla açıklayıcı değişkene ihtiyaç duyulmaktadır (Küçüksille, 2014). Bu nedenlerle, öğretmenlerin eğitim düzeylerinin öğrencilerin akademik başarısındaki belirleyiciliği, birden çok açıklayıcı değişkenin dikkate alınabildiği çoklu doğrusal regresyon yöntemi ile analiz edilerek belirlenebilir. Çoklu doğrusal regresyon modelinin oluşturulabilmesi için öğretmenlerin eğitim düzeyi ile birlikte alanyazın taramasından elde edilen, somut değerlere sahip ve TIMSS-2015 öğretmen ve öğrenci anketinden elde edilen 11 özellik araştırma kapsamında incelenmiştir. Bu değişkenler şunlardır:

- Öğretmenin k1demi (Adeyemi, 2008; Ewetan ve Ewetan, 2015; Sandoval-Hernandez ve diğerleri, 2015),

- $\quad$ Öğrencinin cinsiyeti (Bijou ve Liouaeddine, 2018; Bursal, 2017; Liang, Jones ve Robles-Pina, 2018),

- Kendisine ait bir odasının olması (Kılıç ve Haşıloğlu, 2017; Kırmızı ve İşıüzel, 2014; Yelgün ve Karaman, 2015),

- Evde internet bağlantısı olma durumu (Gelbal, 2010; Torres-Díaz ve diğerleri, 2016; Yavuz, 2018),

- Annenin ve babanın eğitim düzeyleri (Chen, Chen ve Liu, 2019; Jamil ve Khalid, 2016; Sar1er, 2016; Ural ve Çınar, 2014),

- Evdeki dijital bilişim cihazlarının sayısı (BilicanDemir ve Yıldırım, 2015; Elmas ve diğerleri, 2015; Yeşilyurt ve diğerleri 2014),

- Öğretmenin ödev verme siklığg ve ödevleri yapmak için harcanan zaman (Arıkan, 2017; Gustafsson, 2013; Kaya ve Kaya, 2018),

- Özel ders alma/kursa gitme miktarı (Kaya ve Kaya, 2018; Şengül, Kaba ve Erdoğan, 2017; Zhou ve Wang, 2015),

- $\quad$ Evdeki eğitimsel kaynaklar (Özkan, 2018; Tsai ve Yang, 2015; Visser, Juan ve Feza, 2015).

$\mathrm{Bu}$ kapsamda araştırmanın sorusu, "matematik ve fen öğretmenlerinin eğitim düzeyi ortaokul öğrencilerinin matematik ve fen başarısının anlamlı bir belirleyicisi 
midir?" şeklinde belirlenmiştir. Araştırma sorusuna, ortaokul matematik ve fen öğretmenlerine odaklanan veriler ve bulgular ile yanıt bularak, süregelen bu tartışmaya katkıda bulunmak hedeflenmektedir. Özellikle öğretmenlerin eğitim düzeylerinin öğrencilerin ders başarıları üzerindeki etkilerini ele alan bu çalışmanın sonuçları, politika yapıcılara karar verme süreçlerinde somut bir kanıt sağlayabilir. Bu çalışmadan elde edilen veriler, öğretmenlerin mesleğe hazırlanmasını, öğretmen mesleki gelişimini ve istihdam uygulamalarını etkileyen politikaların oluşturulması ve sürdürülmesi süreçlerine bilgi sağlamak için yararlı olabilir.

\section{Yöntem}

$\mathrm{Bu}$ bölümde araştırma modeli, çalışmanın evreni ve örneklemi, verilerin toplanması, veri analizinde kullanılan teknikler ve verilerin güvenirliği açıklanmıştır.

\subsection{Araştırma Modeli}

$\mathrm{Bu}$ araştırma matematik ve fen öğretmenlerinin eğitim düzeylerinin 8. sınıf öğrencilerinin matematik ve fen başarısındaki belirleyiciliğini incelemeyi amaçlayan nicel bir çalışmadır. Nicel araştırma modellerinden ilişkisel tarama modeli kullanılan bu çalışmada TIMSS-2015 değerlendirmesinden elde edilen ikincil verilerin analizleri yapılmıştır. TIMSS-2015, ülkelerin kendi eğitim sistemlerini inceleme firsatı veren ve öğrencilerin fen ve matematik alanlarındaki başarı durumlarının yıllara göre izlenebildiği bir çalışmadır (Milli Eğitim Bakanlığı [MEB], 2003). TIMSS değerlendirmelerinde başarı testlerinin yanında öğrencilere, öğretmenlere, velilere ve okul yöneticilerine sosyoekonomik ve kültürel arka planlarını tespit etmeye yönelik anketler uygulanmaktadır. Söz konusu anketler kullanılarak öğrencilerin akademik başarılarında etkisi olan eğitimsel ve toplumsal faktörlere dair bilgiler toplanmaktadır (Oral ve McGivney, 2013:3). Öğretmen anketinde yer alan eğitim düzeyinin belirlenmesine yönelik soru ile toplanan veriler ve öğrenci başarı puanları bu araştırmada kullanılan ikincil verileri oluşturmaktadır. İkincil verilerin analizinin, birincil verilerden yararlanan çalışmalarla aynı temel araştırma ilkelerini uygulayan ve izlenmesi gereken bir takım adımları olan bir araştırma yöntemi olduğu söylenebilir (Johnston, 2017). İkincil veriler kullanılarak yapılan analizler alanyazının gözden geçirilmesi, farklı araştırma yöntemleriyle özgün araştırma sorularına cevap verilmesi veya eski verilerle yeni soruların yanıtlanması amaciyla mevcut bir veri tabanının analizi şeklinde tanımlanabilir (Turner, 1997). Araştırmacılar, yeni araştırma sorularına cevap bulmak, özgün analizleri desteklemek/genişletmek veya diğer (birincil veya ikincil) veri kaynaklarıyla karşılaştırmak için ikincil verileri kullanabilir (McGinn, 2008). Bu veriler, araştırmacılara yeni hipotezleri incelemeleri ve analiz etmeleri, özgün veri toplama hedefinden ayrı olarak araştırma soruları hakkında bilgi edinmeleri ve özgün araştırma bulgularında bulunmayan yeni ve/veya ek yorumlar ve sonuçlar elde etmeleri için kaynak sağlayabilir (Sherif, 2018). İkincil verilerle yapılan analizlerin, "farklı bağlamlarla, farklı zaman dilimlerinde ve farklı sosyal gruplar ve kültürler arasında karşılaştırmalı araştırmalar yapmak için kullanılabilmesi" (Corti, 2008:802) söz konusu yöntemin bu araştırmada tercih edilme sebebi olmuştur. Bu doğrultuda çalıșmanın yöntemi, ilgili kaynaklardan ikincil verileri toplama, verileri sınıflandırma, analiz etme, kavramsal ve mantıksal çözümlemeler yapma, karşılaştırma, anlama, açıklama, yorumlama ve matematik ve fen öğretmenlerinin eğitim düzeyi açısından değerlendirme yapmaktır. Bu araştırmanın yöntemini planlarken; araştırma sorusuna uygun örneklem seçilmesi, her öğrenci için hesaplanan beş farklı olası değerin analizlere dahil edilmesi, veri analizinin yapılabileceği bir yazılımın kullanılması, öğretmen verileriyle çalışırken bulguların doğru yorumlanması, nedensel çıkarımlar yapılmaması hususlarına dikkat edildiği söylenebilir (Rutkowski ve diğerleri, 2010). Bununla birlikte, bulgular ve sonuçlar, Foy'un (2017) da önerdiği gibi öğretmenlerin eğitim düzeylerinin öğrenme süreçlerinin bir öğesi olan öğrenciler odak noktasına alınarak rapor edilmiştir.

\subsection{Evren ve Örneklem}

TIMSS'e katılan her ülke TIMSS örnekleme yöntemlerini uygulamak için ülkenin Ulusal Araştırma Koordinatörü ve TIMSS örnekleme uzmanlarını içeren ortak bir çalışma yürütmektedir (Martin, Mullis ve Hooper, 2016). İki aşamalı tabakalı örnekleme yönteminin kullanıldığı TIMSS-2015'de ilk aşamada öğrenci sayıları ile doğru orantılı olacak şekilde okullar seçilmekte, ikinci aşamada ise bu okullardan bir veya iki sınıf seçilmektedir (Yıldırım ve diğerleri, 2013). Seçilen sınıflardaki öğrencilerin tümü değerlendirmeye alınmaktadır. Bu örnekleme yaklaşımları göz önüne alındığında, TIMSS çalışmalarında evrendeki her öğrencinin eşit olasılıkla seçildiği basit bir rastgele örnekleme yaklaşımının takip edilmediği açıktır (Rutkowski ve diğerleri, 2010). TIMSS-2015 değerlendirmesinde katılımcı ülkeleri temsil eden ve bu çalışmada yararlanılan örneklem kümesine ilişkin sayılar Tablo 1'de sunulmuştur.

Tablo 1. Çalışma Kapsamındaki Ülkelere İlişkin Örneklem

\begin{tabular}{lc}
\hline \multicolumn{1}{c}{ Ülke } & Örneklem Sayısı \\
\hline Güney Afrika & 12514 \\
Singapur & 6116 \\
Suudi Arabistan & 3759 \\
Türkiye & 6079 \\
\hline Toplam & 28468 \\
\hline
\end{tabular}

Tablo 1'de dağılımı verilen 8. sınıf matematik ve fen alanlarında ilk ve son sırayı alan ülkeler ile Türkiye'den değerlendirmeye alınan 28468 öğrencinin tamamı araştırmaya dahil edilmiştir. TIMSS-2015 veri tabanındaki öğretmenlerin katılımcı ülkelerdeki öğretmenleri temsil etmemesinin, örneklem konusunda dikkat edilmesi gereken bir konu olduğu düşünülmektedir. Bu öğretmenler, ülkeleri temsil eden örneklem kümesini oluşturan öğrencilerin öğretmenleridir. $\mathrm{Bu}$ nedenle, öğretmen verileriyle yapılan analizlerin, bu çalışmada olduğu gibi analiz birimi olan öğrencilerle birlikte yapılması TIMSS-2015 kullanıcı rehberi dokümanında tavsiye edilmektedir (Foy, 2017).

\subsection{Verilerin Toplanmas1}

Verilerin toplanması aşamasında öncelikle ikincil verilerin analizinin yapılmasına hazırlık olarak, birincil veri setleri ile araştırmanın amacı arasındaki uygunluğun bir 
değerlendirmesi yapılmıştır (Long-Sutehall, Sque ve Addington-Hall, 2011). Bu çalışmada, TIMSS-2015 8. sınıf matematik ve fen alanı değerlendirmelerinde ilk sırayı alan Singapur, matematik alanında sonuncu olan Suudi Arabistan, fen alanında sonuncu olan Güney Afrika ve iki alanda da orta sıralarda yer alan Türkiye'nin verileri incelenmiştir. Verilere, Uluslararası Eğitim Başarılarını Değerlendirme Kuruluşu'nun (International Association for the Evaluation of Education Achievement, IEA) internet sitesinden erişilmiştir. IEA'nın açık erişime sunduğu veri tabanından, ülkelerin matematik ve fen alanlarında yapılan başarı testleri puanlarına ve öğretmenlerin eğitim düzeylerini belirlemeye yönelik uygulanan anket sonuçlarına ulaşılabilmektedir. Bu veriler, TIMSS-2015'de uluslararası hedef evren olarak belirlenen, ilköğretimin ilk yılından itibaren 4. ve 8. yıldaki örgün eğitimi temsil eden sınıflardaki öğrenci, öğretmen ve idarecilerden elde edilmektedir (Martin, Mullis ve Hooper, 2016). Tablo 2'de çalışma kapsamındaki ülkelerin hedef evreninin özellikleri sunulmaktadir.

Tablo 2. Çalışma Kapsamındaki Ülkelerin Hedef Evreninin Özellikleri (Martin, Mullis ve Hooper, 2016).

\begin{tabular}{lcc}
\hline \multicolumn{1}{c}{ Ülke } & Resmi Eğitim Yılı & Test Zamanındaki Ortalama Yaş \\
\hline Güney Afrika & 9 & 15.7 \\
Singapur & 8 & 14.4 \\
Suudi Arabistan & 8 & 14.1 \\
Türkiye & 8 & 13.9 \\
\hline
\end{tabular}

Tablo 2'de verilen resmi eğitim yılı ve test zamanındaki ortalama yaşlar dikkate alındığında, Singapur, Suudi Arabistan ve Türkiye'nin TIMSS-2015 hedef evreninin kapsamına uyduğu söylenebilir. Güney Afrika'nın ise TIMSS-2015'in taleplerini karş1layabilmek ve daha iyi karşılaştırmalar elde etmek için dokuzuncu sınıf öğrencileriyle değerlendirmeye alındığı Martin, Mullis ve Hooper (2016) tarafindan belirtilmektedir.

TIMSS-2015 değerlendirmesinde evreni tam olarak temsil edebilecek öğrencilerden verilerin toplanması amaçlanmasına rağmen nadiren de olsa bazı okul ve öğrenci gruplarının hedef evreninin dışında bırakılması gerekebilir (Martin, Mullis ve Hooper, 2016). Tablo 3'te çalışma kapsamındaki ülkelerin hedef evreninin dışında bırakılan öğrencilerin oranı verilmektedir.

Tablo 3. Çalışma Kapsamındaki Ülkelerin Hedef Evreninin Dışında Bırakılan Öğrenci Oranları (Mullis ve diğerleri, 2016; Martin ve diğerleri, 2016).

\begin{tabular}{lccc}
\hline \multicolumn{1}{c}{ Ülke } & $\begin{array}{c}\text { Okul Düzeyinde } \\
\text { Dışarda Birakılma (\%) }\end{array}$ & $\begin{array}{c}\text { Bireysel Düzeyde } \\
\text { Dişarda Bırakılma (\%) }\end{array}$ & $\begin{array}{c}\text { Toplam } \\
(\%)\end{array}$ \\
\hline Güney & 1.5 & 0 & 1.5 \\
Afrika & 7 & 0 & 7 \\
Singapur & 1.9 & 0.2 & 2.1 \\
Suudi & 0.2 & 1.1 & 1.3 \\
Arabistan & Türkiye &
\end{tabular}

Dışarda bırakılan öğrencilerin toplam miktarının, bir ülkedeki hedef evrenin \%5'inden fazlasını oluşturmaması koşulu IEA'nın dokümanlarında belirtilmektedir (Martin, Mullis ve Hooper, 2016). Tablo 3'e göre Singapur bu koşulu sağlamamaktadır. Ancak, Singapur'da okul düzeyinde dışarda bırakılmaların özel gereksinimli bireylerin okullarından ve özel amaçlı okullardan kaynaklanması nedeniyle bu koșul ihmal edilmiștir (Martin, Mullis ve Hooper, 2016).

TIMSS-2015 değerlendirmesinde verilerin toplanması aşamasında üzerinde durulan bir diğer konunun ise katılım oranları olduğu söylenebilir (Rutkowski ve diğerleri, 2010). TIMSS-2015'de örneklenen okullar, sınıflar ve öğrenciler tarafından \% 100 katılım sağlanması arzu edilmekle birlikte asgari \%75 veya 85 oranındaki (IEA'nın koşullarına bağlı olarak değişmektedir) katılımlar kabul edilmektedir (Martin, Mullis ve Hooper, 2016). Tablo 4'te çalışma kapsamındaki ülkelerin katılım oranları sunulmaktadır.

Tablo 4. Çalışma Kapsamındaki Ülkelerin Katılım Oranları (Mullis ve diğerleri, 2016; Martin ve diğerleri, 2016).

\begin{tabular}{lccc}
\hline \multicolumn{1}{c}{ Ülke } & $\begin{array}{c}\text { Okul Katılımı } \\
(\%)\end{array}$ & $\begin{array}{c}\text { Sınıf Katılımı } \\
(\%)\end{array}$ & $\begin{array}{c}\text { Öğrenci Katılımı } \\
(\%)\end{array}$ \\
\hline Güney Afrika & 100 & 100 & 96 \\
Singapur & 100 & 100 & 97 \\
Suudi Arabistan & 100 & 100 & 97 \\
Türkiye & 100 & 100 & 98 \\
\hline
\end{tabular}

Tablo 4'e bakıldığında, çalışma kapsamındaki ülkelerin tamamının katılım oranlarında IEA'nın belirlediği koşulu sağladığ1 görülmektedir. IEA'nın belirlediği koşulları sağlayarak TIMSS-2015 değerlendirmesine alınan ülkelerden toplanan veriler istatistiksel analiz yazılımlarının veri dosyası formatlarında sunulmaktadır. Bu faktörler göz önüne alınarak yapılan değerlendirmede, söz konusu bu verilerin araştırmanın amacı doğrultusunda yapılacak istatistiksel analizlerde kullanılabileceğine karar verilmiştir.

IEA'nın veri tabanında katılımcı tüm ülkelerin hem konu alanlarındaki başarı testlerine hem de farklı kategoride incelenen öğrenci başarısını etkileyen faktörlere ait verilere yer verilmektedir. Dolayısıyla bu durum, büyük hacimli bir veri yığını içerisinden araştırmanın odağı gözden kaçırılmadan verilerin toplanmasını gerektirmiştir. Veri yığınlarının incelemesinde; veri toplama, analiz ve raporlama için verilerin ayrıma tabi tutulması ilk aşamadır (White ve Marsh, 2006). Bu doğrultuda, ulaşılan büyük veri yığını içinden araştırmanın amacına uygun olanlar seçilerek analize hazır hale getirilmiştir.

\subsection{Verilerin Güvenirliği}

Sekizinci sınıf matematik ve fen testlerinin güvenirlik katsayıları Tablo 5'te verilmektedir. Bu katsayılar, tüm TIMSS-2015 değerlendirme kitapçıklarındaki Cronbach's Alpha güvenirliğidir. Genel olarak, güvenirliklerin yüksek olduğu söylenebilir.

Tablo 5. Çalışma Kapsamındaki Ülkeler İçin Cronbach's Alpha Güvenirlik Katsayısı (Martin, Mullis ve Hooper, 2016).

\begin{tabular}{lcc}
\hline \multicolumn{1}{c}{ Ülke } & Matematik & Fen \\
\hline Güney Afrika & 0.80 & 0.82 \\
Singapur & 0.91 & 0.87 \\
Suudi Arabistan & 0.76 & 0.79 \\
Türkiye & 0.91 & 0.87 \\
\hline
\end{tabular}

\subsection{Verilerin Analizi}

Verilerin analizinde, Andersen, Prause ve Silver'ın (2011) ikincil verilerin analizi için sunduğu dört adımdan oluşan kılavuzdan yararlanılmıştır. Birinci adım, araştırmanın 
gereksinimlerine uygun olan ikincil verileri belirlemektir. $\mathrm{Bu}$ adımda, araştırmanın amacı kapsamında kişiselleştirilmiş bir veri dosyasının oluşturulmasını planlamak için gereken veriler tespit edilmiştir. İkinci adım, kişiselleştirilmiş veri kümesi meydana getirmektir. Özgün karşılaştırmalar yapabilmek ve ilgili kurguları benzer şekilde açıklayan veriler elde edebilmek için geniş bir veri yığını içerisinden birbirine benzeyen verilerin bir araya getirilerek anlaşılır bir halde düzenlenmesi bu aşamada gerçekleştirilmiştir. İkincil veri analizinin üçüncü adımı, çalışma kapsamında toplanan verilerin nicel analizlere uygun olmasından dolayı atlanarak dördüncü adıma geçilmiştir. Dördüncü ve son adım, istatistiksel analizlerdir. TIMSS gibi geniş ölçekli değerlendirme çalışmalarının verilerinin kullanıldığ 1 istatistiksel analizler için IEA tarafından geliştirilen IDB Analyzer 4.0 programı bu çalışmada tercih edilmiştir. IDB Analyzer 4.0 programı, TIMSS değerlendirmesindeki anket sorularına cevap verilememesi gibi nedenlerden meydana gelen kayı veriler, örnekleme ağırlıkları (sampling weights), her öğrenci için hesaplanan beş farklı olası değer (plausible values), varyans tahmin yöntemleri (jackknife tekrarlı çoğaltma [jackknife repeated replication], JRR) gibi TIMSS-2015 veri setinin özelliklerini dikkate alarak hesaba katılmasına olanak vermektedir. IDB Analyzer 4.0 programı, analiz için uygun ağırlık ve tekrarlama değişkenlerini otomatik olarak seçerek analizlere dahil etmektedir.

İstatistiksel analizlere geçmeden önce, veri setindeki öğretmenlerin, eğitim düzeylerine ve mesleki kıdemlerine ilişkin soruya cevap vermemelerinden kaynaklanan kayıp veriler ile lisans ve lisansüstü eğitim düzeyleri haricindeki cevaplar belirlenerek veri setinden çıkarılmıştır. Kayıp veri içeren gözlemlerin veri setinden çıkartılabilmesi için kayıp verilerin tamamen tesadüfi olarak dağılıyor olması varsayımının sağlanması gerekmektedir (Çüm ve diğerleri, 2018). Demir ve Parlak'a (2012:232) göre, tamamen tesadüfi kayıp varsayımı, "bir değişkendeki kayıp verilerin olasılığının, bu değişkenin kendi değeriyle ya da veri setindeki diğer herhangi bir değişkenin değeriyle ilişkili olmadığını" gösteren bir varsayımdır. Bu varsayım veri setindeki tüm değişkenler için anlamlı olduğunda, geride kalan veriler, orijinal veri setinin basit seçkisiz bir örneklemi olarak kabul edilebilir (Allison, 2002). Silinen verilerin öğretmen kaynaklı veriler olması nedeniyle, hem kendi değerini hem de veri setindeki diğer herhangi bir değişkenin değerini etkilemediği açıkça görüldügüunden geride kalan verilerin orijinal veri setini temsil ettiği kabul edilebilir. Tablo 6 , verilerin analizinde kullanılan veri miktarlarını göstermektedir.

Tablo 6. Verilerin Analizinde Kullanılan Veri Miktarları

\begin{tabular}{lccc}
\hline \multicolumn{1}{c}{$\begin{array}{c}\text { Analize Konu } \\
\text { Olan Alan }\end{array}$} & $\begin{array}{c}\text { Orijinal Veri } \\
\text { Sayıs1 }\end{array}$ & $\begin{array}{c}\text { Silinen Veri } \\
\text { Say1S1 }\end{array}$ & $\begin{array}{c}\text { Analize Giren } \\
\text { Veri Say1s1 }\end{array}$ \\
\hline Matematik & 15954 & 1779 & 14175 \\
Fen & 24709 & 4706 & 20003 \\
\hline
\end{tabular}

Veri silme işleminin ardından geriye kalan veri setini oluşturan öğrenciler ile bu öğrencilerin matematik ve fen öğretmenlerinin eğitim düzeyleri (lisans/lisansüstü) ve mesleki kıdemleri birbirleriyle eşleştirilmiştir. Araştırma konusuyla ilgili genel bir fikir verebilmesi için, ülkelerin
TIMSS-2015 8. sinıf matematik ve fen değerlendirmesinden elde ettikleri başarı puanları ile bu ülkeleri temsil eden öğrencilerin matematik ve fen öğretmenlerinin eğitim durumlarını gösteren betimsel istatistiklere yer verilmiştir.

$\mathrm{Bu}$ çalışmada, matematik ve fen bilgisi başarı puanları üzerinde öğretmenlerin eğitim düzeylerinin belirleyiciliğinin incelenmesi için oluşturulan çoklu doğrusal regresyon matematiksel modeli şu şekilde yazılabilir:

$\mathrm{y}=\beta_{0}+\beta_{1} \mathrm{x}_{1}+\beta_{2} \mathrm{x}_{2}+\beta_{3} \mathrm{x}_{3}+\beta_{4} \mathrm{x}_{4}+\beta_{5} \mathrm{x}_{5}+\beta_{6} \mathrm{x}_{6}+\beta_{7} \mathrm{x}_{7}+\beta_{8} \mathrm{x}_{8}+\beta_{9} \mathrm{x}_{9}+\beta_{10}$ $\mathrm{x}_{10}+\beta_{11} \mathrm{x}_{11}+\beta_{12} \mathrm{x}_{12}+\varepsilon$

y : Matematik/fen başarı puanları (1-5 olası değer)

$\beta_{\mathrm{n}}:$ Kısmi regresyon katsayısı

$\mathrm{x}_{1}$ : Öğretmenlerin eğitim düzeyi

$\mathrm{x}_{2}$ : Öğretmenlerin mesleki kıdemi

$\mathrm{x}_{3}$ : Öğrencinin cinsiyeti

$\mathrm{x}_{4}$ : Kendisine ait bir odasının olması

$\mathrm{x}_{5}$ : Evde internet bağlantısı olma durumu

$\mathrm{x}_{6}$ : Annesinin eğitim düzeyi

$\mathrm{x}_{7}$ : Babasının eğitim düzeyi

$\mathrm{X}_{8}$ : Evdeki dijital bilgi cihazlarının sayısı

$\mathrm{X}_{9}$ : Ödevleri yapmak için harcanan zaman

$\mathrm{x}_{10}$ : Öğretmenin ödev verme sıklığ1

$\mathrm{x}_{11}$ : Özel ders alma / kursa gitme miktarı

$\mathrm{x}_{12}$ : Evdeki eğitimsel kaynaklar

$\varepsilon \quad$ : Hata terimi

Analize giren sınıflamalı değişkenlerin bağımlı değişken üzerindeki etkisinin incelenebilmesi için gerekli olan dummy değişkenler (Büyüköztürk, 2013), IDB Analyzer 4.0 programı tarafindan otomatik olarak üretilmektedir. IDB Analyzer 4.0n yalnızca örneklem tasarımını yansıtan katsayıları ve örnekleme hatalarını tahmin etmek için uygun araçlar sağlamakta olup çoklu regresyon hakkındaki varsayımların (normallik, doğrusallık, çoklu bağlantılılık) doğrulanması gerektiği söylenebilir (Mirazchiyski, 2014). Matematik ve fen alanlarında hesaplanan beş farklı olası değer dikkate alınarak oluşturulan normallik ve doğrusallık varsayımlarının incelenmesine ilişkin grafiklerin, bağımlı ve bağımsız değişkenler arasında doğrusal bir ilişki olduğunu ve normal dağılım eğrilerinin de normale yakın bir dağılımı gösterdiği ileri sürülebilir. Yordayıcı değişkenler arasında çoklu bağlantılılık sorunu olup olmadığını kontrol etmek amaciyla yapılan korelasyon matrisi Tablo 7'de verilmektedir. Tablo 7'de verilen değerlere göre, yordayıcı değişkenler arasındaki karşılıklı korelasyonlar alanyazında önerilen kriter sınırı olan 0.80 değerini (Büyüköztürk, 2013) aşmadığı görülmektedir. Her ülke için ayrı ayrı yapılan korelasyon matrislerinde de 0.80 değerinin üzerinde bir değer hesaplanmamıştır. Bu nedenle, bu çalışmanın yordayıcı değişkenler arasında çoklu bağlantılılık sorunun olmadığı öne sürülebilir. 
Tablo 7. Yordayıcı Değişkenler Arasındaki Korelasyon Matrisi

\begin{tabular}{|c|c|c|c|c|c|c|c|c|c|c|c|c|c|}
\hline \multicolumn{2}{|c|}{ Değişkenler } & 1 & 2 & 3 & 4 & 5 & 6 & 7 & 8 & 9 & 10 & 11 & 12 \\
\hline \multirow{12}{*}{ 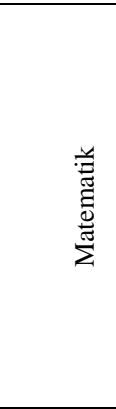 } & 1 & 1,00 & & & & & & & & & & & \\
\hline & 2 & 10 & 1,00 & & & & & & & & & & \\
\hline & 3 & ,06 &, 02 & 1,00 & & & & & & & & & \\
\hline & 4 & ,06 & ,11 &,- 04 & 1,00 & & & & & & & & \\
\hline & 5 & \begin{tabular}{|l|}
,- 01 \\
\end{tabular} &,- 02 & \begin{tabular}{|c|}
,- 01 \\
\end{tabular} &,- 12 & 1,00 & & & & & & & \\
\hline & 6 &,- 03 &,- 07 &, 04 &,- 27 & ,15 & 1,00 & & & & & & \\
\hline & 7 & ,11 &, 08 &, 09 &, 13 &,- 10 &,- 10 & 1,00 & & & & & \\
\hline & 8 &, 08 &, 09 &, 04 &, 15 &,- 09 &,- 11 &, 58 & 1,00 & & & & \\
\hline & 9 &,- 02 & 00 & 04 &,- 01 & ,01 & 00 & 01 & ,00 & 1,00 & & & \\
\hline & 10 &, 04 & ,01 &,- 07 & $\begin{array}{l}, 03 \\
\end{array}$ & ,00 &,- 02 & ,01 & ,00 &,- 07 & 1,00 & & \\
\hline & 11 & ,01 & ,05 &, 03 & ,03 & $\begin{array}{l}-, 07 \\
\end{array}$ & $\begin{array}{l}-01 \\
\end{array}$ & ,05 & ,04 & ,01 & ,05 & 1,00 & \\
\hline & 12 &, 08 &, 13 &,- 02 &, 35 &,- 40 &,- 38 & ,36 & ,39 &,- 01 &, 05 &, 13 & 1,00 \\
\hline \multirow{12}{*}{ एँ } & 1 & 1,00 &, 05 &,- 04 & ,04 &,- 02 &,- 03 & & & & & & \\
\hline & 2 &, 05 & 1,00 &,- 02 &, 12 &,- 04 &,- 09 & & & & & & \\
\hline & 3 &,- 04 &,- 02 & 1,00 & ,01 &,- 07 & 00 & & & & & & \\
\hline & 4 & ,04 & ,12 & ,01 & 1,00 &,- 15 &,- 28 & & & & & & \\
\hline & 5 &,- 02 &,- 04 &,- 07 &,- 15 & 1,00 & 15 & & & & & & \\
\hline & 6 &,- 03 &,- 09 & 00 &,- 28 &, 15 & 1,00 & & & & & & \\
\hline & 7 & ,01 & ,07 & ,06 & ,16 & $\begin{array}{l}-, 09 \\
\end{array}$ &,- 11 & 1,00 & & & & & \\
\hline & 8 & ,01 & 07 &, 03 &, 14 &,- 07 &,- 11 & ,56 & 1,00 & & & & \\
\hline & 9 & $\begin{array}{l}-, 01 \\
\end{array}$ & ,07 &,- 05 & ,04 & ,03 & $\begin{array}{l}-02 \\
\end{array}$ & ,01 & 02 & 1,00 & & & \\
\hline & 10 &, 02 & ,01 &,- 05 & ,02 & , 01 &,- 02 &,- 01 & , 00 &,- 09 & 1,00 & & \\
\hline & 11 &,- 01 & ,02 & 00 & ,02 &,- 07 &,- 02 & ,01 & ,01 &,- 07 & 06 & 1,00 & \\
\hline & 12 & ,04 &, 12 & ,01 & ,39 &,- 44 &,- 42 & ,33 &, 33 & \begin{tabular}{l|}
,- 02 \\
\end{tabular} &, 03 & ,10 & 1,00 \\
\hline \multicolumn{5}{|c|}{ 1. Öğretmenin Eğitim Düzeyi } & \multicolumn{4}{|c|}{ 2. Öğretmenin mesleki kıdemi } & \multicolumn{5}{|c|}{ 3. Öğrencinin cinsiyeti } \\
\hline \multicolumn{5}{|c|}{ 4. Evdeki dijital bilgi cihazlarının sayıs1 } & \multirow{2}{*}{\multicolumn{4}{|c|}{$\begin{array}{l}\text { 5. Kendisine ait bir odasının olması } \\
\text { 8. Babanın eğitim düzeyi }\end{array}$}} & \multicolumn{5}{|c|}{ 6. Evde internet bağlantısı olma durumu } \\
\hline \multicolumn{5}{|c|}{ 7. Annenin eğitim düzeyi } & & & & & \multirow{2}{*}{\multicolumn{5}{|c|}{ 12. Evdeki eğitimsel kaynaklar }} \\
\hline \multicolumn{5}{|c|}{ 10. Ev ödevi yapmak için harcanan zaman } & \multicolumn{4}{|c|}{ 11. Özel ders alma/kursa gitme miktarı } & & & & & \\
\hline
\end{tabular}

\section{Bulgular ve Yorumlar}

TIMSS-2015 8. sınıf matematik alanında ilk ve son sıray alan ülkeler ile Türkiye'den değerlendirmeye katılan öğrencilerin, matematik öğretmenlerinin lisans ve lisansüstü eğitim düzeylerine göre başarı puan ortalamaları Tablo 8'de sunulmuştur.

Tablo 8. Matematik Değerlendirmesine Katılan Öğrencilerin, Öğretmenlerinin Eğitim Düzeylerine Göre Puan Ortalamaları

\begin{tabular}{|c|c|c|c|c|c|c|c|c|}
\hline \multirow{2}{*}{$\begin{array}{l}\text { TIMSS } 2015 \\
\text { Derecesi }\end{array}$} & \multirow{2}{*}{ Ülke } & \multirow{2}{*}{ Puan } & \multicolumn{2}{|c|}{$\begin{array}{l}\text { Doktora Eğitim Almış } \\
\text { Öğretmenler }\end{array}$} & \multicolumn{2}{|c|}{$\begin{array}{l}\text { Yüksek Lisans Eğitimi Almış } \\
\text { Öğretmenler } \\
\end{array}$} & \multicolumn{2}{|c|}{ Lisans Eğitimi Almış Öğretmenler } \\
\hline & & & $(\%)$ & $\begin{array}{c}\text { Öğrencilerin Puan } \\
\text { Ortalaması }\end{array}$ & $(\%)$ & Öğrencilerin Puan Ortalaması & $(\%)$ & $\begin{array}{c}\text { Öğrencilerin Puan } \\
\text { Ortalamas1 }\end{array}$ \\
\hline 1 & Singapur & 621 & - & - & 10.99 & 634.13 & 89.01 & 618.08 \\
\hline 24 & Türkiye & 458 & 0.67 & 594.06 & 6.56 & 514.82 & 92.77 & 453.50 \\
\hline 39 & $\begin{array}{l}\text { Suudi } \\
\text { Arabistan }\end{array}$ & 368 & - & - & 3.49 & 433.55 & 96.51 & 370.52 \\
\hline
\end{tabular}

Tablo 8 incelendiğinde, TIMSS-2015 8. sınıf matematik başarı sıralamasında ilk sırayı alan Singapur'da lisansüstü eğitim almış öğretmenlerin oranının, Türkiye'den yaklaşık 1.5 kat, son sıradaki Suudi Arabistan'dan ise yaklaşık üç kat daha fazla olduğu görülmektedir. Lisansüstü eğitime sahip olan öğretmenlerin öğrencilerinin matematik puan ortalamaları, lisans mezunu öğretmenlerin öğrencilerinden yüksektir. Puan ortalamalarının istatistiksel olarak anlamlı olup olmadığına bakabilmek için IDB Analyzer 4.0 programının hesapladığı ve Tablo 9'da sunulan t değerleri kullanılabilir. Tablo 9'da sunulan ' $t$ ' değerleri dikkate alındığında, Singapur ve Suudi Arabistan'dan değerlendirmeye katılan öğrenciler arasındaki puan farklılıklarının istatistiksel olarak anlamlı olmadığı söylenebilir $\quad\left(\mathrm{t}_{\text {Singapur }}=1.22, \quad \mathrm{p}>0.01 ; \quad \mathrm{t}_{\text {SuudiArabistan }}=.82\right.$, $\mathrm{p}>0.01)$. Türkiye'de ise tüm gruplar arasındaki puan fark1 istatistiksel olarak anlamlı bulunmuştur $\left(\mathrm{t}_{\mathrm{L}-\mathrm{YL}}=3.55, \mathrm{p}<0.01\right.$; $\left.\mathrm{t}_{\mathrm{L}-\mathrm{Dr}}=6.92, \mathrm{p}<0.01 ; \mathrm{t}_{\mathrm{YL}-\mathrm{Dr}}=2.992, \mathrm{p}<0.01\right)$.

Tablo 9. Matematik Puanları İçin " $t$ " Değerleri

\begin{tabular}{lccc}
\hline \multicolumn{1}{c}{ Ülke } & $\begin{array}{c}\text { Referans Eğitim } \\
\text { Düzeyi }\end{array}$ & $\begin{array}{c}\text { Karşılaştırılan Eğitim } \\
\text { Düzeyi }\end{array}$ & t değeri \\
\hline Suudi & Lisans & Yüksek Lisans & .82 \\
Arabistan & Lisans & Yüksek Lisans & 1.22 \\
\hline Singapur & Lisans & Yüksek Lisans & $3.55^{*}$ \\
\multirow{2}{*}{ Türkiye } & Lisans & Doktora & $6.92^{*}$ \\
& Yüksek Lisans & Doktora & $2.99^{*}$ \\
\hline
\end{tabular}


Tablo 9'daki değerlere göre istatistiksel olarak anlamlı bulunan gruplarda etki büyüklüğüne bakılabilmesi için Cohen d istatistiği hesaplanmıştır. 3.55, 6.92 ve 2.99'luk t değerlerine karşılık gelen d değerleri sırasıyla $0.21,1.44$ ve 0.64 'tür. Buna göre, meydana gelen farkların etki büyüklügüünun lisans ve yüksek lisans eğitim düzeyi için düşük, lisans ve doktora düzeyi için yüksek, yüksek lisans ve doktora düzeyi için ise orta olduğu ifade edilebilir (Büyüköztürk, 2013). İstatistiksel farkın etki büyüklügüünün yüksek olması, Türkiye'deki öğrencilerin matematik puanlarında öğretmenlerin lisans ve doktora eğitim düzeyleri arasındaki farklılıkların güçlü bir etkiye sahip olduğunu işaret etmektedir. Türkiye'deki öğrencilerin matematik puanlarında öğretmenlerin lisans ve yüksek lisans mezunu olmalarının etkisinin düşük olduğu söylenebilir.

PISA-2015 değerlendirmesine Singapur, Türkiye ve Suudi Arabistan'dan katılan 8. sınıf öğrencilerinin matematik başarısında öğretmenlerin eğitim düzeyinin belirleyiciliğini açıklamak için başarıda etkisi olan diğer değişkenleri de kullanarak çoklu regresyon analizi yapılmıştır. Regresyon analizi, öğretmen ve öğrenci değişkenlerinin dahil edildiği genel regresyon modelinin Singapur (düzeltilmiş $R^{2}=0.21$, $\mathrm{F}_{(11,5750)}=138.95$ ve $\mathrm{p}<0.01$ ), Türkiye (düzeltilmiş $\mathrm{R}^{2}=0.26$, $\mathrm{F}_{(11,4966)}=158.62$ ve $\mathrm{p}<0.01$ ) ve Suudi Arabistan (düzeltilmiş $\mathrm{R}^{2}=0.17, \mathrm{~F}_{(11,2054)}=38.25$ ve $\left.\mathrm{p}<0.01\right)$ için istatistiksel olarak anlamlı olduğunu göstermektedir. Üç ülke için yapılan regresyon analizine ilişkin değerler Tablo 10'da verilmiştir.

Tablo 10. TIMSS-2015'e Türkiye'den Katılan 8. Sınıf Öğrencilerinin Matematik Başarısının Belirleyicilerine İlişkin Çoklu Regresyon Sonuçları

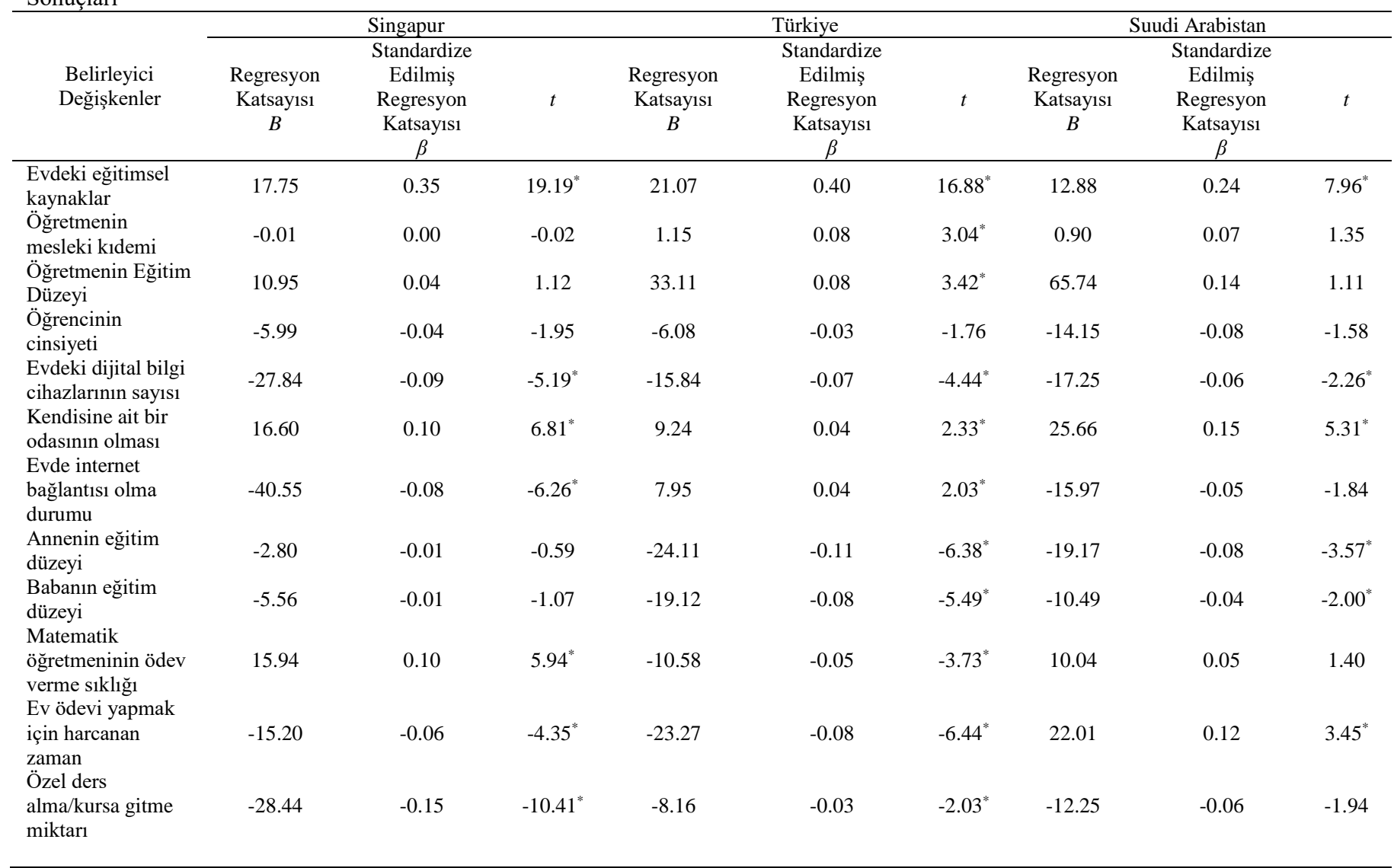

t değeri $\mathrm{p}<0.05$ düzeyinde anlamlıdır.

Tablo 10'da verilen değerlere göre 12 belirleyici değişkenden yedisinin Singapur'dan, 11'inin Türkiye'den ve 6'sının Suudi Arabistan'dan değerlendirmeye katılan 8 . sınıf öğrencilerinin matematik başarısına istatistiksel olarak anlamlı katkı yaptığı söylenebilir. Öğretmenlerin eğitim düzeyinin ise Singapur'dan ve Suudi Arabistan'dan değerlendirmeye alınan öğrencilerin matematik başarısında istatistiksel olarak anlamlı bir belirleyici olmadığı öne sürülebilir. Belirleyici değişkenlerin $\beta$ katsayısı dikkate alınarak göreli önem sıralaması yapıldığında, öğretmenlerin eğitim düzeyinin Türkiye'deki öğrencilerin matematik başarısında üçüncü önemli belirleyici olduğu ifade edilebilir.

TIMSS-2015 8. sinıf fen alanında ilk ve son sirayı alan ülkeler ile Türkiye'den değerlendirmeye katılan öğrencilerin, fen öğretmenlerinin lisans ve lisansüstü eğitim düzeylerine göre başarı puan ortalamaları Tablo 11'de sunulmuştur. 
Tablo 11. Fen Değerlendirmesine Katılan Öğrencilerin, Öğretmenlerinin Eğitim Düzeylerine Göre Puan Ortalamaları

\begin{tabular}{|c|c|c|c|c|c|c|c|c|}
\hline \multirow{2}{*}{$\begin{array}{l}\text { TIMSS } 2015 \\
\text { Derecesi }\end{array}$} & \multirow{2}{*}{ Ülke } & \multirow{2}{*}{ Puan } & \multicolumn{2}{|c|}{$\begin{array}{l}\text { Doktora Eğitim Almış } \\
\text { Öğretmenler }\end{array}$} & \multicolumn{2}{|c|}{$\begin{array}{l}\text { Yüksek Lisans Eğitimi Almış } \\
\text { Öğretmenler }\end{array}$} & \multicolumn{2}{|c|}{ Lisans Eğitimi Almış Öğretmenles } \\
\hline & & & $(\%)$ & $\begin{array}{c}\text { Ögrencilerin Puan } \\
\text { Ortalaması }\end{array}$ & $(\%)$ & Öğrencilerin Puan Ortalaması & $(\%)$ & $\begin{array}{c}\text { Öğrencilerin Puan } \\
\text { Ortalaması }\end{array}$ \\
\hline 1 & Singapur & 597 & - & - & 18.17 & 605.00 & 81.83 & 594.52 \\
\hline 21 & Türkiye & 493 & 2.09 & 491.10 & 5.03 & 521.95 & 92.88 & 491.98 \\
\hline 39 & Güney Afrika & 358 & - & - & 5.19 & 431.89 & 94.81 & 358.90 \\
\hline
\end{tabular}

Tablo 11 incelendiğinde, TIMSS-2015 8. sınıf fen başarı sıralamasında ilk sırayı alan Singapur'da lisansüstü eğitim almış öğretmenlerin oranının, Türkiye'den ve Güney Afrika'dan yaklaşık 3.5 kat daha fazla olduğu görülmektedir. Lisansüstü eğitime sahip olan öğretmenlerin öğrencilerinin fen puan ortalamaları, lisans mezunu öğretmenlerin öğrencilerinden yüksektir. Türkiye'de doktora eğitimi almış öğretmenlerin öğrencileri lisans eğitimi almış öğretmenlerin öğrencileriyle hemen hemen aynı puan ortalamasına sahiptir. Puan ortalamalarının istatistiksel olarak anlamlı olup olmadığına bakabilmek için IDB Analyzer 4.0 programının hesapladığ 1 ve Tablo 12 'de sunulan $\mathrm{t}$ değerleri kullanılabilir.

Tablo 12. Fen Puanları İçin " $t$ " Değerleri

\begin{tabular}{lccc}
\hline \multicolumn{1}{c}{ Ülke } & $\begin{array}{c}\text { Referans Eğitim } \\
\text { Düzeyi }\end{array}$ & $\begin{array}{c}\text { Karşılaştırılan Ĕ̆itim } \\
\text { Düzeyi }\end{array}$ & t değeri \\
\hline Güney Afrika & Lisans & Yüksek Lisans & $2.36^{*}$ \\
\hline Singapur & Lisans & Yüksek Lisans & .91 \\
\hline \multirow{2}{*}{ Türkiye } & Lisans & Yüksek Lisans & 1.89 \\
& Lisans & Doktora & -.03 \\
& Yüksek Lisans & Doktora & -.88 \\
\hline
\end{tabular}

${ }^{*} t$ değeri $\mathrm{p}<0.01$ düzeyinde anlamlıdır.

Tablo 12'de sunulan “ $t$ " değerleri dikkate alındığında, Singapur ve Türkiye'den değerlendirmeye katılan öğrenciler arasındaki puan farklılıklarının istatistiksel olarak anlamlı olmadığı söylenebilir $\left(\mathrm{t}_{\text {Singapur }}=.91, \mathrm{p}>0.01\right.$; $\mathrm{t}_{\text {TürkiyeL-YL }}=1.89, \mathrm{p}>0.01 ; \mathrm{t}_{\text {TürkiyeL-Dr }}=-.03, \mathrm{p}>0.01 ; \mathrm{t}_{\text {TürkiyeYL- }}$ $\mathrm{Dr}=-.88, \mathrm{p}>0.01)$. Güney Afrika'da ise lisans mezunu ve yüksek lisans mezunu öğretmenlerin öğrencilerinin fen puanları arasında istatistiksel olarak anlamlı bir fark bulunmuştur ( $\mathrm{t}_{\text {GüneyAfrika }}=2.36, \mathrm{p}<0.01$ ). İstatistiksel olarak anlamlı bulunan bu grupta etki büyüklüğüne bakılabilmesi için Cohen $\mathrm{d}$ istatistiği hesaplanmıştır. $\mathrm{t}=2.36$ değerine karş1lık gelen d değeri 0.14'tür. Buna göre, meydana gelen farkların etki büyüklüğünün lisans ve yüksek lisans eğitim düzeyi için düşük olduğu ifade edilebilir (Büyüköztürk, 2013). Güney Afrika'daki öğrencilerin fen puanlarında ögretmenlerin lisans ve yüksek lisans mezunu olmalarının etkisinin düşük olduğu söylenebilir.

PISA-2015 değerlendirmesine Singapur, Türkiye ve Güney Afrika'dan katılan 8. sınıf öğrencilerinin fen başarısında öğretmenlerin eğitim düzeyinin belirleyiciliğini açıklamak için başarıda etkisi olan diğer değişkenleri de kullanarak çoklu regresyon analizi yapılmıştır. Regresyon analizi, öğretmen ve öğrenci değişkenlerinin dahil edildiği genel regresyon modelinin Singapur (düzeltilmiş $\mathrm{R}^{2}=0.23$, $\mathrm{F}_{(11,5757)}=156.33$ ve $\mathrm{p}<0.01$ ), Türkiye (düzeltilmiş $\mathrm{R}^{2}=0.24$, $\mathrm{F}_{(11,5083)}=145.92$ ve $\mathrm{p}<0.01$ ) ve Güney Afrika (düzeltilmiş $\mathrm{R}^{2}=0.19, \mathrm{~F}_{(11,6227)}=132.79$ ve $\left.\mathrm{p}<0.01\right)$ için istatistiksel olarak anlamlı olduğunu göstermektedir. Üç ülke için yapılan regresyon analizine ilişkin değerler Tablo 13 'te verilmiştir.

Tablo 13. TIMSS-2015'e Türkiye'den Katılan 8. Sınıf Öğrencilerinin Fen Başarısının Belirleyicilerine İlişkin Çoklu Regresyon Sonuçları

\begin{tabular}{|c|c|c|c|c|c|c|c|c|c|}
\hline \multirow[b]{2}{*}{ Belirleyici Değişkenler } & \multicolumn{3}{|c|}{ Singapur } & \multicolumn{3}{|c|}{ Türkiye } & \multicolumn{3}{|c|}{ Güney Afrika } \\
\hline & $\begin{array}{c}\text { Regresyon } \\
\text { Katsayis1 } \\
B\end{array}$ & $\begin{array}{c}\text { Standardize } \\
\text { Edilmiş } \\
\text { Regresyon } \\
\text { Katsayisı } \\
\beta \\
\end{array}$ & $t$ & $\begin{array}{c}\text { Regresyon } \\
\text { Katsayis1 } \\
B\end{array}$ & $\begin{array}{c}\text { Standardize } \\
\text { Edilmiş } \\
\text { Regresyon } \\
\text { Katsayisı } \\
\beta \\
\end{array}$ & $t$ & $\begin{array}{c}\text { Regresyon } \\
\text { Katsayis1 } \\
B\end{array}$ & $\begin{array}{c}\text { Standardize } \\
\text { Edilmiş } \\
\text { Regresyon } \\
\text { Katsayisı } \\
\beta \\
\end{array}$ & $t$ \\
\hline $\begin{array}{l}\text { Evdeki eğitimsel } \\
\text { kaynaklar }\end{array}$ & 21.93 & 0.41 & $22.50^{*}$ & 19.28 & 0.40 & $17.26^{*}$ & 14.06 & 0.23 & $5.38^{*}$ \\
\hline $\begin{array}{l}\text { Öğretmenin mesleki } \\
\text { kıdemi }\end{array}$ & 0.09 & 0.01 & 0.26 & 0.74 & 0.07 & $2.78^{*}$ & 1.00 & 0.10 & 1.82 \\
\hline $\begin{array}{l}\text { Öğretmenin Eğitim } \\
\text { Düzeyi }\end{array}$ & 6.87 & 0.03 & 0.87 & 13.52 & 0.03 & 1.42 & 44.52 & 0.10 & 1.87 \\
\hline Öğrencinin cinsiyeti & 5.93 & 0.04 & 1.94 & -15.42 & -0.08 & $-5.66^{*}$ & -0.53 & 0.00 & -0.11 \\
\hline $\begin{array}{l}\text { Evdeki dijital bilgi } \\
\text { cihazlarının sayısı }\end{array}$ & -29.88 & -0.09 & $-5.18^{*}$ & -10.62 & -0.06 & $-3.13^{*}$ & -30.47 & -0.14 & $-6.96^{*}$ \\
\hline $\begin{array}{l}\text { Kendisine ait bir } \\
\text { odasının olması }\end{array}$ & 19.58 & 0.12 & $7.16^{*}$ & 7.26 & 0.04 & 1.95 & 21.19 & 0.09 & $4.55^{*}$ \\
\hline $\begin{array}{l}\text { Evde internet bağlantısı } \\
\text { olma durumu }\end{array}$ & -34.08 & -0.06 & $-3.81^{*}$ & 6.30 & 0.03 & 1.77 & -34.19 & -0.16 & $-6.95^{*}$ \\
\hline $\begin{array}{l}\text { Annenin eğitim düzeyi } \\
\text { Babanın eğitim düzeyi }\end{array}$ & $\begin{array}{l}-6.03 \\
-1.21\end{array}$ & $\begin{array}{l}-0.02 \\
0.00\end{array}$ & $\begin{array}{l}-1.17 \\
-0.22\end{array}$ & $\begin{array}{l}-21.96 \\
-16.91\end{array}$ & $\begin{array}{l}-0.11 \\
-0.08\end{array}$ & $\begin{array}{l}-6.65^{*} \\
-5.22^{*}\end{array}$ & $\begin{array}{l}-9.89 \\
-2.65\end{array}$ & $\begin{array}{l}-0.03 \\
-0.01\end{array}$ & $\begin{array}{l}-1.70 \\
-0.39\end{array}$ \\
\hline $\begin{array}{l}\text { Fen öğretmeninin ödev } \\
\text { verme siklığ } 1\end{array}$ & 6.92 & 0.04 & $2.96^{*}$ & -6.70 & -0.03 & $-2.42^{*}$ & 8.26 & 0.04 & $2.17^{*}$ \\
\hline $\begin{array}{l}\text { Ev ödevi yapmak için } \\
\text { harcanan zaman }\end{array}$ & -23.18 & -0.09 & $-6.66^{*}$ & -10.21 & -0.05 & $-2.78^{*}$ & -2.88 & -0.01 & -0.65 \\
\hline $\begin{array}{l}\text { Özel ders alma/kursa } \\
\text { gitme miktarı }\end{array}$ & -26.41 & -0.12 & $-9.68^{*}$ & -8.85 & -0.04 & $-2.38^{*}$ & -25.67 & -0.10 & $-4.12^{*}$ \\
\hline
\end{tabular}

\footnotetext{
t değeri $\mathrm{p}<0.05$ düzeyinde anlamlıdır.
}

Tablo 13'te verilen değerlere göre 12 belirleyici değişkenden yedisinin Singapur'dan, 9'unun Türkiye'den ve 6'sının Güney Afrika'dan değerlendirmeye katılan 8 . sınıf öğrencilerinin fen başarısına istatistiksel olarak 
anlamlı katkı yaptığı söylenebilir. Öğretmenlerin eğitim düzeyinin ise üç ülkenin öğrencilerinin fen başarısında istatistiksel olarak anlamlı bir belirleyici olmadığı öne sürülebilir.

\section{Tartıșma, Sonuc ve Öneriler}

Bu çalışmada, TIMSS 2015 değerlendirmesinde ilk ve son sırayı alan ülkeler ile Türkiye'nin 8. sınıf öğretmen ve öğrenci anketi verileri ve her öğrenci için hesaplanan beşer adet matematik ve fen olası değerleri kullanılarak, öğretmenlerin eğitim düzeyinin öğrencilerin matematik ve fen puanları üzerindeki belirleyiciliği incelenmiştir. Elde edilen bulguların istatiksel olarak anlamlı olup olmadıkları analiz edilmiş ve ülkeler arası benzerlik ve farklılıklara bakılmıştır. $\mathrm{Bu}$ çalışmanın bulgularının, öğretmenlerin eğitim düzeylerinin, 8. sınıf öğrencilerinin matematik ve fen başarısında belirleyici bir faktör olmadığını gösteren bilimsel kanıtlar sunduğu ifade edilebilir. $\mathrm{Bu}$ sonuçların, hem Türkiye hem de değerlendirmede birinci ve sonuncu olan ülkeler için benzerlikler taşıdığı söylenebilir.

Çalışmada ilk olarak matematik öğretmenlerinin eğitim düzeylerinin 8 . sınıf öğrencilerinin matematik puanlarındaki belirleyiciliği araştırılmıştır. Çoklu regresyon analizinde, Singapur ve Suudi Arabistan'daki matematik öğretmenlerinin eğitim düzeylerinin öğrencilerin matematik puanlarındaki belirleyiciliğinde istatistiksel olarak anlamlı olmadığı bulgusundan yola çıkarak öğretmenlerin eğitim düzeyinin öğrencilerin matematik başarısını belirleyen bir faktör olmadığı sonucuna ulaşılabilir. Singapur ve Suudi Arabistan'daki lisansüstü eğitimi olan matematik öğretmenlerinin öğrencilerinin matematik puanları ile lisans mezunu öğretmenlerin öğrencilerinin puanları arasında istatistiksel olarak anlamlı bir fark olmaması bu sonucu destekleyen bilimsel bir kanıt olarak gösterilebilir. Bu sonuçların, alanyazındaki diğer çalışmalarla (Jepsen, 2005; Rivkin, Hanushek ve Kain, 2005; Sirait, 2016) tutarl olduğu belirtilebilir. Burada, Türkiye'yi diğer ülkelerden ayıran önemli bir sonuç, Türkiye'de doktora eğitimi almış öğretmenlerin öğrencilerinin puanlarının hem lisans hem de yüksek lisans eğitimi almış öğretmenlerin öğrencilerinden istatistiksel olarak anlamlı ve etkili bir şekilde yüksek olmasıdır. Çoklu regresyon analizinde de Türkiye'deki öğrencilerin matematik başarısı üzerinde matematik öğretmenlerinin eğitim düzeyinin belirleyici bir faktör olarak bulunmasının bu sonuçla paralellik gösterdiği ifade edilebilir. Türkiye'deki öğretmenlerin eğitim düzeyinin belirleyici bir faktör olarak bulunmasının nedeni doktoralı öğretmenlerin öğrencilerinin TIMSS-2015 değerlendirmesine katılarak puan ortalamasını lisansüstü eğitimli öğretmenlerin öğrencileri lehine artırması olabilir. Diğer iki ülkeden değerlendirmeye katılan öğrencilerin doktoralı matematik öğretmeni olmadığı için bu konuda bir sonuca varılamamıştır. Bu sonuçlara göre, Türkiye'deki matematik öğretmenlerinin mezun olduğu lisansüstü programların, öğrencilerin matematik başarısının belirleyicisi olması bağlamında belirli bir önem düzeyinde yer aldığı ancak bu öğretmenlerin öğrencilerinin puanlarının Singapur'daki lisans mezunu öğretmenlerin öğrencilerinden düşük olduğu dikkate alındığında yeterli nitelikte olmadığı ileri sürülebilir.

Fen öğretmenlerinin eğitim düzeylerinin 8 . sınıf ögrencilerin fen puanlarındaki belirleyiciliği incelendiğinde, araştırmaya dahil edilen üç ülkedeki yüksek lisans eğitimi olan fen öğretmenlerinin öğrencilerinin fen puanları ile lisans mezunu öğretmenlerin öğrencilerinin puanları arasındaki farkın Singapur ve Türkiye için istatistiksel olarak anlamlı olmadığ 1 , Güney Afrika'da ise anlamlı fakat etki büyüklügüünun düşük olduğu görülebilir. Çoklu regresyon analizinde de her üç ülkedeki fen öğretmenlerinin eğitim düzeylerinin öğrencilerin fen puanlarındaki belirleyiciliğinin istatistiksel olarak anlamlı bulunmadığı bulgusundan yola çıkarak öğretmenlerin eğitim düzeyinin öğrencilerin fen başarısını belirleyicisi olmadığı sonucuna ulaşılabilir. $\mathrm{Bu}$ sonuçların, alanyazındaki araştırmaların (Mubarak ve Razak, 2017; Zhang ve Campbell, 2015) sonuçları ile benzerlik gösterdiği söylenebilir.

Güçlü akademik geçmişe sahip öğretmenlerin öğrencilerinin akademik açıdan daha başarılı olabilecekleri kanısının ve alanyazında yer alan bu yöndeki çalışmaların (Abazaoğlu ve Taşar, 2016; Athar ve Jamal, 2017; DarlingHammond, 2000; Goldhaber ve Brewer, 1996,1997) aksine bu araştırmada öğretmenlerin eğitim düzeyinin öğrencilerin matematik ve fen başarılarında belirleyici bir faktör olmadığı sonucuna ulaşılmasının farklı nedenleri olabilir. Nedenlerden birisi, öğretmenlerin lisansüstü eğitimlerde elde ettiği kazanımların kalıcılığının uzun sürmemesi olabilir. Harris ve Sass (2007), özellikle mezun olmadan uzun zaman önce derslerini alan öğretmenlerin derslerden edindikleri kazanımları öğrencilerine yansıtma sürelerinin fazla olmayabileceğini ifade etmektedir. Mezuniyet tezi yazmanın uzun sürmesi, lisansüstü eğitim içeriğindeki derslerin öğrenci başarısını artırmaya doğrudan katkı yapacak içeriklerde olmaması gibi nedenler de buna dahil edilebilir. Ayrica, ortaokul matematik ve fen programlarında yer alan kazanımlar, öğretmenlerin ileri akademik eğitimlere sahip olmasını gerektirecek kadar üst düzeyde olmayabilir. Örneğin, Eke'nin (2018) çalışmasında Türkiye'deki ortaokul fen bilimleri dersi öğretim programı kazanımlarının birçoğunun Webb'in bilgi derinliği seviyelerinin ikinci seviyesi olan beceriler/kavramlar basamağında olduğu belirlenmiştir. İncikabı ve diğerlerinin (2016) Türkiye'de uygulanan ortaokul $(5,6,7,8)$ matematik dersi öğretim programını TIMSS 2015 matematik çerçevesinde ifade edilen bilişsel alanlar ve alt boyutlar dâhilinde inceledikleri çalışmada da hatırlama, karar verme, genelleme ve doğrulama alt boyutları ile ilişkili kazanımların hiçbir sınıf düzeyinde ve paralel olarak öğrenme alanında yer almadığı belirtilmektedir. Türkiye'deki matematik ve fen programlarında karşılaşılan bu durum diğer ülkeler için de geçerli olabilir. Diğer bir neden, TIMSS-2015'in anket tasarımından kaynaklanabilir. TIMSS-2015'de öğretmenlere yüksek lisans ve doktora derecesine sahip olup olmadığı sorulmuş ancak lisansüstü eğitim aldığ (2011) araştırmasına göre, öğretmenlerin alanlarına özgü lisansüstü eğitimlerinin, öğretmenin etkinliği üzerinde güçlü bir etkisi bulunmaktadır. Alanyazındaki araştırmalardan bazılarında konu alanında ve eğitim alanında yapılan lisansüstü eğitimlerin öğrenci başarısına katkıda bulunabileceği gösterilmiştir (Collier, 2013; Dee ve Cohodes, 2008; Goldhaber ve Brewer, 1996,1997). Badgett ve diğerleri (2013) de öğretmenlerin lisansüstü eğitim alanlarında ayrım yapılmamasının araştırmaların sonuçlarını maskeleyebileceğinden söz etmektedir. 
Öğretmenlerin lisansüstü eğitim alanlarının belli olmaması nedeniyle lisansüstü eğitim derecelerinin öğrencinin akademik başarısı üzerindeki belirleyiciliği ortaya çıkmamış olabilir. Tüm bu nedenlerin yanında; bazı ülkelerde lisansüstü eğitimin Türkiye'deki gibi düșük nitelikte olması (Günay, 2018; Şen, 2013; Tonbul, 2017), bazı ülkelerde ise öğretmen lisans eğitiminin Singapur'daki gibi yüksek nitelikte olması (Erbilgin ve Boz, 2013; Kabaran ve Görgen, 2016; Levent ve Yazıc1, 2014) ortaokul seviyesindeki öğretmenler arasındaki nitelik farkını ve buna bağlı olarak öğrencilerin akademik başarılarında öğretmenin eğitim düzeyinin belirleyiciliğini ortadan kaldırabilir.

$\mathrm{Bu}$ çalışmanın sonuçlarına dayalı olarak uygulayıcılara ve araştırmacılara yönelik aşağıdaki önerilerde bulunulabilir:

Uygulayıcılara Yönelik Öneriler;

1. Fen öğretmenlerin eğitim düzeylerinin 8 . sınıf öğrencilerinin fen başarısında belirleyici bir faktör olmadığı, evdeki eğitimsel kaynakların, evdeki dijital bilgi cihazlarının sayısının, öğretmenin ödev verme sıklığının, fenden özel ders almanın/kursa gitmenin fen başarısında belirleyici olduğu yönünde sonuçlar elde edilmiştir. TIMSS gibi uluslararası değerlendirmelerde fen alanında başarılı olmak ve ortaokul öğrencilerinin fen başarılarını artırmak için eğitim konusundaki karar vericiler ve politika yapıcılar, akademik başarı üzerinde istatistiksel olarak anlamlı olan belirleyici faktörlere ağırlık verebilir. $\mathrm{Bu}$ belirleyici faktörler arasında önem düzeyi en yüksek olan evdeki eğitimsel kaynaklardır. Türkiye'de ders kitapları öğrencilere ücretsiz olarak verilen basılı tek eğitimsel kaynaktır. Ayrıca, MEB'in 2023 Eğitim Vizyonu belgesinde açıkladığı gibi öğretmenlerin mesleki gelişimi, lisansüstü düzeyde desteklenecektir. Ortaokul fen öğretmenlerine lisansüstü eğitim yaptırmak için ayrılan kamu kaynakları, ortaokul öğrencilerine dağıtılan fen ders kitabı yanında fen dersini destekleyici başka eğitimsel kaynakların verilmesi için kullanılabilir.

2. Türkiye'deki doktorası olan matematik öğretmenlerinin öğrencilerinin puanları ile lisans mezunu öğretmenlerin öğrencilerinin puanları arasındaki istatistiksel olarak anlamlı farkın etki büyüklüğünün yüksek olduğu ve matematik öğretmenlerinin eğitim düzeylerinin 8 . sınıf öğrencilerinin matematik başarısında belirleyici bir faktör olduğu saptanmıştır. Lisans ve yüksek lisans mezunu matematik öğretmenlerinin öğrencileri arasındaki istatistiksel olarak anlamlı olan puan farklarının etki büyüklüğü ise düşüktür. Dolayısıyla, yüksek lisansını tamamlamış matematik öğretmenlerinin doktora eğitimi yapabilmeleri için uygun koşullar sağlanabilir ve bu konuda teşvik edilebilirler.

3. TIMSS-2015 değerlendirmesinde ilk, orta ve son sirayı alan ülkelerde öğretmenlerin lisans ve yüksek lisans eğitimlerinin 8. sınıf öğrencilerinin akademik başarısı üzerinde belirleyici bir etkisi olmadığı yönünde bilimsel kanıtlar elde edilmiştir. Öğretmenlerin yüksek lisans eğitiminde elde ettikleri ileri düzeydeki kazanımları ortaokul seviyesinde basitleştirebilmelerini ve açıklayabilmelerini destekleyebilecek içeriklere sahip olan ve yalnızca ortaokul öğretmenlerine yönelik yüksek lisans programları açılabilir.
1. Bu çalışmanın analizleri öğrencilerin matematik ve fen test başarı puanlarına endekslidir. $\mathrm{Bu}$ puanlar, tek oturumluk ve yalnızca bir sınavdan alınmış puanlardır. Öğrencilerin sürece yayılmış matematik ve fen başarıları ile öğretmenlerin eğitim düzeyleri arasındaki ilişkiyi inceleyen araştırmaların yapılması, bu konudaki bilimsel kanıt çeşitliliğini artırabilir.

2. Öğretmenlerin eğitim düzeyleri ve öğrencilerin başarı düzeyleri arasındaki ilişkiyi, başarıda etkisi olan farklı değişkenleri göz önüne alarak inceleyebilecek ulusal çapta veri setleri kullanan araştırmalar yapılması, ortaokul matematik ve fen öğretmeni yetiştirme ve istihdamı konusundaki karar vericilere ve politika yapıcılara daha sağlıklı bulgular sağlayabilir.

3. Öğretmenlerin eğitim düzeyleri ile akademik başarı dışındaki eğitimsel çıktılar arasındaki ilişkiler araştırılabilir.

\section{Kaynakça}

Abazaoğlu, İ. ve Taşar, M. F. (2016). Fen bilgisi öğretmen özelliklerinin öğrenci fen başarısı ile ilişkisi: TIMSS 2011 verilerine göre bir durum analizi (Singapur, Güney Kore, Japonya, İngiltere, Türkiye). Illkögretim Online, 15(3), 922-945.

Adeyemi, T. O. (2008). Teachers' teaching experience and students' learning outcomes in secondary schools in Ondo State, Nigeria. Asian Journal of Information Technology, 7(5), 201-209.

Aliyu, U. A., Yashe, A. ve Adeyeye, A. C. (2013). Effect of teachers qualifications on performance in further mathematics among secondary school students. Mathematical Theory and Modeling, 3(11), 140-146.

Allison, P. D. (2002). Missing data. Thousand Oaks, CA: Sage Publications, Inc.

Andersen, J. P., Prause, J. ve Silver, R. C. (2011). A Stepby-step guide to using secondary data for psychological research. Social and Personality Psychology Compass, 5(1), 56-75.

Arıkan, S. (2017). TIMSS 2011 verilerine göre Türkiye'deki ev ödevi ve matematik başarısı arasındaki ilişki. International Journal of Eurasia Social Sciences, 8(26), 256-276.

Aslam, U., Rehman, M., Imran, M. K. ve Muqadas, F. (2016). The impact of teacher qualifications and experience on student satisfaction: a mediating and moderating research model. Pakistan Journal of Commerce and Social Sciences (PJCSS), 10(3), 505524.

Athar, M. R. ve Jamal, N. (2017). Academic achievement of students associated with professional education of teacher. Journal of Research and Reflections in Education, 11(2), 94-99.

Badgett, K., Decman, J. ve Carman, C. (2013). National implications: The impact of teacher graduate degrees on student math assessments. National Forum of Teacher Education Journal, 23(3), 1-18.

Araştırmacılara yönelik öneriler; 
Bijou, M. ve Liouaeddine, M. (2018). Gender and students' achievements: Evidence from PISA 2015. World Journal of Education, 8(4), 24-35.

Bilican-Demir, S. ve Yıldırım, Ö. (2015). Okulda ve okul dışında bilgi ve iletişim teknolojilerinin kullanımının öğrencilerin PISA 2012 performansıyla ilişkisinin incelenmesi. Kastamonu Eğitim Dergisi, 24(1), 251262.

Bratsch-Hines, M. E., Vernon-Feagans, L., Varghese, C. ve Garwood, J. (2017). Child skills and teacher qualifications: Associations with elementary classroom teachers' reading instruction for struggling readers. Learning Disabilities Research \& Practice, 32(4), 270283.

Buddin, R. ve Zamarro, G. (2009). Teacher qualifications and student achievement in urban elementary schools. Journal of Urban Economics, 66(2), 103-115.

Bursal, M. (2017). Academic achievement and perceived peer support among Turkish students: Gender and preschool education impact. International Electronic Journal of Elementary Education, 9(3), 599-612.

Büyüköztürk, Ş. (2013). Sosyal bilimler için veri analizi el kitabı: Istatistik, araştırma deseni SPSS uygulamaları ve yorum. Ankara: Pegem A Yayıncilık.

Chen, S. H., Chen, Y. C. ve Liu, J. T. (2019). The impact of family composition on educational achievement. Journal of Human Resources, 54(1), 122-170.

Coenen, J., Groot, W., van den Brink, H. M. ve Van Klaveren, C. (2014). Teacher characteristics and their effects on student test scores: A best-evidence review. Maastricht: TIER.

Coleman, J. S., Campbell, E. Q., Hobson, C. J., McPartland, J., Mood, A. M., Weinfeld, F. D. ve York, R. L. (1966). Equality of educational opportunity. Washington DC: US Government Printing Office.

Collier, T. C. (2013). Teacher qualifications and student achievement: A panel data analysis. Review of Applied Economics, 9(1076-2017-2359), 1-20.

Connor, C. M., Son, S. H., Hindman, A. H. ve Morrison, F. J. (2005). Teacher qualifications, classroom practices, family characteristics, and preschool experience: Complex effects on first graders' vocabulary and early reading outcomes. Journal of School Psychology, 43(4), 343-375.

Corti, L. (2008). Secondary analysis. İçinde: L. M. Given(Ed.), The Sage Encyclopedia of Qualitative Research Methods Volumes 1\&2 (s.801-803). Thousand Oaks, California: SAGE Publications, Inc.

Croninger, R. G., Rice, J. K., Rathbun, A. ve Nishio, M. (2007). Teacher qualifications and early learning: Effects of certification, degree, and experience on firstgrade student achievement. Economics of Education Review, 26(3), 312-324.

Çüm, S., Demir, E. K., Gelbal, S. ve Kışla, T. (2018). Kayıp veriler yerine yaklaşık değer atamak için kullanılan gelişmiş yöntemlerin farklı koşullar altında karşılaștırılması. Mehmet Akif Ersoy Üniversitesi Eğitim Fakültesi Dergisi, 45, 230-249.

Darling-Hammond, L. (2000). Teacher quality and student achievement. Education Policy Analysis Archives, 8(1), $1-44$.

DeAngelis, K. J. ve Presley, J. B. (2011). Teacher qualifications and school climate: Examining their interrelationship for school improvement. Leadership and Policy in Schools, 10(1), 84-120.

Dee, T. S. ve Cohodes, S. R. (2008). Out-of-field teachers and student achievement: Evidence from matched-pairs comparisons. Public Finance Review, 36(1), 7-32.

Demir, E. ve Parlak, B. (2012). Türkiye'de eğitim araştırmalarında kayıp veri sorunu. Eğitimde ve Psikolojide Ölçme ve Değerlendirme Dergisi, 3(1), 230241.

Dodeen, H., Abdelfattah, F., Shumrani, S. ve Hilal, M. A. (2012). The effects of teachers' qualifications, practices, and perceptions on student achievement in TIMSS mathematics: A comparison of two countries. International Journal of Testing, 12(1), 61-77.

Ehrenberg, R. G. ve Brewer, D. J. (1994). Do school and teacher characteristics matter? Evidence from high school and beyond. Economics of Education Review, 13(1), 1-17.

Eke, C. (2018). Fen bilimleri dersi öğretim programındaki kazanımların Webb'in bilgi derinliği seviyelerine göre analizi. Sosyal Araştırmalar ve Davranış Bilimleri Dergisi, 4(6), 174-190.

Elmas, O., Kete, S., Hizlisoy, S. S. ve Kumral, H. N. (2015). Teknolojik cihaz kullanım alışkanlıklarının okul başarısı üzerine etkisi. SDÜ Sağlık Bilimleri Dergisi, 6(2), 49-54.

Erbilgin, E. ve Boz, B. (2013). Matematik öğretmeni yetiştirme programlarımızın Finlandiya, Japonya ve Singapur programları ile karşılaştırması. Hacettepe Üniversitesi Eğitim Fakültesi Dergisi, Özel(1), 156-170.

Ewetan, T. O. ve Ewetan, O. O. (2015). Teachers' teaching experience and academic performance in mathematics and English language in public secondary schools in Ogun State, Nigeria. International Journal of Humanities, Social Sciences and Education, 2(2), 123134.

Feng, L. ve Sass, T. R. (2013). What makes specialeducation teachers special? Teacher training and achievement of students with disabilities. Economics of Education Review, 36, 122-134.

Ferguson, R. F. ve Ladd, H. F. (1996). How and why money matters: An analysis of Alabama schools. İçinde: H. F. Ladd (Ed.), Holding Schools Accountable: Performance-based Reform in Education (s.265-298). Washington, DC: The Brookings Institution.

Foy, P. (2017). TIMSS 2015 User guide for the international database. Chestnut Hill, MA: IEA.

Gage, N. A., Adamson, R., MacSuga-Gage, A. S. ve Lewis, T. J. (2017). The relation between the academic 
achievement of students with emotional and behavioral disorders and teacher characteristics. Behavioral Disorders, 43(1), 213-222.

Gelbal, S. (2010). Sekizinci sınıf öğrencilerinin sosyoekonomik özelliklerinin Türkçe başarısı üzerinde etkisi. Ĕgitim ve Bilim, 33(150), 1-13.

Goldhaber, D. ve Brewer, D. J. (1996). Evaluating the effect of teacher degree level on educational performance. Rockford, MD: Westat, Inc.

Goldhaber, D. ve Brewer, D. J. (1997). Evaluating the effect of teacher degree level on educational performance. İçinde: J.W. Fowler (Ed.), Developments in School Finance 1996 (s.197-210). Washington: National Center for Education Statistics, U.S. Department of Education.

Goldhaber, D. ve Brewer, D. J. (1998). When should we reward degrees for teachers? The Phi Delta Kappan, 80(2), 134-138.

Gustafsson, J. E. (2013). Causal inference in educational effectiveness research: A comparison of three methods to investigate effects of homework on student achievement. School Effectiveness and School Improvement, 24(3), 275-295.

Günay, D. (2018). Türkiye'de lisansüstü eğitim ve lisansüstü eğitime felsefi bir bakış. Üniversite Araştırmaları Dergisi, 1(2), 71-88.

Harris, D. N. ve Sass, T. R. (2007). Teacher training, teacher quality, and student achievement. Washington, D.C.: National Center for Analysis of Longitudinal Data in Education Research.

Ingersoll, R. M. (2007). A comparative study of teacher preparation and qualifications in six nations. İçinde: Richard M. Ingersoll (ed.), A Comparative Study of Teacher Preparation and Qualifications in Six Nations, Consortium for Policy Research in Education (s.1-18). Philadelphia, PA: CPRE.

İncikabı, L., Ayanoğlu, P., Aliustaoğlu, F., Tekin, N. ve Mercimek, O. (2016). Ortaokul matematik dersi öğretim programı kazanımlarının TIMSS bilişsel alanlarına göre değerlendirilmesi. Illkögretim Online, 15(4), 1149-1163.

Jamil, F. ve Khalid, R. (2016). Predictors of academic achievement in primary school students. Pakistan Journal of Psychological Research, 31(1), 45-61.

Jepsen, C. (2005). Teacher characteristics and student achievement: Evidence from teacher surveys. Journal of Urban Economics, 57(2), 302-319.

Johnston, M. P. (2017). Secondary data analysis: A method of which the time has come. Qualitative and Quantitative Methods in Libraries, 3(3), 619-626.

Kabaran, G. G. ve Görgen, I. (2016). Güney Kore, Hong Kong, Singapur ve Türkiye'deki öğretmen yetiştirme sistemlerinin karşılaştırmalı olarak incelenmesi. Bartın Üniversitesi Eğitim Fakültesi Dergisi, 5(2), 478-495.

Karakelle, S. (2005). Öğretmenlerin etkili öğretmen tanımlarının etkili öğretmenlik boyutlarına göre incelenmesi. Ĕgitim ve Bilim, 30(135), 1-10.
Kaya, V. H. ve Kaya, E. (2018). Fen başarısını artırmak için ödevler ve kurslar gerekli midir? Anadolu Ögretmen Dergisi, 2(1), 48-62.

Kılıç, Y. ve Haşıloğlu, M. A. (2017). Sosyoekonomik durumun öğrenci başarısına etkisi (7. sınıf Türkçe ve fen bilimleri dersleri örneklemi). Yüzüncü $Y_{l} l$ Üniversitesi Eğitim Fakültesi Dergisi, 14(1), 10251049.

Kırmızı, B. ve İşıüzel, B. (2014). Almanca derslerinde öğrenci başarısını etkileyen faktörlerin belirlenmesi. Fırat Üniversitesi Sosyal Bilimler Dergisi, 24(1), 13-24.

Küçüksille, E. (2014). Çoklu doğrusal regresyon modeli. İçinde: Şeref Kalaycı (ed.), SPSS Uygulamalı Çok Değişkenli İstatistik Teknikleri (s.258-269). Ankara: Asil Yayın Dağıtım.

Lai, F., Sadoulet, E. ve De Janvry, A. (2011). The contributions of school quality and teacher qualifications to student performance evidence from a natural experiment in Beijing middle schools. Journal of Human Resources, 46(1), 123-153.

Levent, F. ve Yazıc1, E. (2014). Singapur eğitim sisteminin başarısına etki eden faktörlerin incelenmesi. Marmara Üniversitesi Atatürk Eğitim Fakültesi Eğitim Bilimleri Dergisi, 39(39), 121-143.

Liang, Y. W., Jones, D. ve Robles-Pina, R. A. (2018). Ethnic and gender stereotypes on college students' academic performance. Research in Higher Education Journal, $35 . \quad$ (Erişim: 02/02/2019), http://www.aabri.com/manuscripts/182858.pdf

Link, C. R. ve Ratledge, E. C. (1979). Student perceptions, IQ and achievement. Journal of Human Resources, 14(1), 98-111.

Long-Sutehall, T., Sque, M. ve Addington-Hall, J. (2011). Secondary analysis of qualitative data: a valuable method for exploring sensitive issues with an elusive population? Journal of Research in Nursing, 16(4), 335344.

Maphoso, L. S. T. ve Mahlo, D. (2015). Teacher qualifications and pupil academic achievement. Journal of Social Sciences, 42(1-2), 51-58.

Martin, M. O., Mullis, I. V., Foy, P. ve Hooper, M. (2016). TIMSS 2015 international results in science. Chestnut Hill, MA: IEA.

Martin, M. O., Mullis, I. V. ve Hooper, M. (2016). Methods and procedures in TIMSS 2015. Chestnut Hill, MA: IEA.

McGinn, K. (2008). Secondary data. İçinde: L. M. Given (Ed.), The Sage Encyclopedia of Qualitative Research Methods Volumes 1\&2 (s.803-804). Thousand Oaks, California: SAGE Publications, Inc.

MEB. (2003). TIMMS 1999 Üçüncü uluslararası matematik ve fen bilgisi çallşması ulusal rapor. Ankara: MEB Eğitimi Araştırma ve Geliştirme Dairesi Başkanlığı.

Mirazchiyski, P. (2014). Analyzing the TALIS data using the IEA IDB Analyzer. İçinde: Alena Becker (ed.), 
TALIS User Guide for the International Database (s.2872). Paris: OECD Publishing.

Mubarak, A. A. ve Razak, N. A. (2017). Malaysian students' achievement in TIMSS 2011: Does Science inquiry really matter? Malaysian Journal of Learning and Instruction (MJLI), Special issue on Graduate Students Research on Education, 1-25.

Mullis, I. V., Martin, M. O., Foy, P. ve Hooper, M. (2016). TIMSS 2015 international results in mathematics. Chestnut Hill, MA: IEA.

Muriithi, E. M. P. (2018). Effect of teacher characteristics on learner academic achievement in physics in Kenyan secondary schools. International Journal of Education and Research, 6(3), 165-178.

Musau, L. M. ve Abere, M. J. (2015). Teacher qualification and students' academic performance in science mathematics and technology subjects in Kenya. International Journal of Educational Administration and Policy Studies, 7(3), 83-89.

Nye, B., Konstantopoulos, S. ve Hedges, L. V. (2004). How large are teacher effects? Educational Evaluation and Policy Analysis, 26(3), 237-257.

Oduh, W. A. ve Okanigbuan, P. N. (2014). Relationship between teachers' qualification and students' performance in mathematics among students of private secondary schools in Ikpoba-Okha Local Government Area of Edo State, Nigeria. Journal of Emerging Trends in Educational Research and Policy Studies, 5(4), 416422.

Ojera, D. A. (2016). Impact of teacher qualification on pupils' academic achievement in Kenya certificate of primary education in public primary schools of Migori County, Kenya. World Journal of Educational Research, 3(7), 1-20.

Oktay, A. (1991). Öğretmenlik mesleği ve öğretmenin nitelikleri. Marmara Üniversitesi Atatürk Eğitim Fakültesi Ĕ̆itim Bilimleri Dergisi, 3(3), 187-193.

Oral, I. ve McGivney, E. (2013). Türkiye'de matematik ve fen bilimleri alanlarında ögrenci performansi ve başarının belirleyicileri TIMSS 2011 analizi. İstanbul: Eğitim Reformu Girişimi.

Özkan, U. B. (2018). TIMSS-2015 sonuçlarının evde bulunan eğitimsel kaynaklar açısından karşılaştırmalı olarak değerlendirilmesi. Amasya Üniversitesi Ĕ̌itim Fakültesi Dergisi, 7(1), 98-120.

Richardson, A. (2008). An examination of teacher qualifications and student achievement in mathematics. Doktora Tezi. Auburn, Alabama: Auburn University.

Rivkin, S. G., Hanushek, E. A. ve Kain, J. F. (2005). Teachers, schools, and academic achievement. Econometrica, 73(2), 417-458.

Rowan, B., Correnti, R. ve Miller, R. J. (2002). What largescale, survey research tells us about teacher effects on student achievement: Insights from the prospectus study of elementary schools. Philadelphia, PA: CPRE Publications.
Rutkowski, L., Gonzalez, E., Joncas, M. ve von Davier, M. (2010). International large-scale assessment data: Issues in secondary analysis and reporting. Educational Researcher, 39(2), 142-151.

Sandoval-Hernandez, A., Jaschinski, K., Fraser, P. ve Ikoma, S. (2015). Is teacher experience associated with mathematics achievement? Amsterdam: IEA.

Sarıer, Y. (2016). Türkiye'de öğrencilerin akademik başarısını etkileyen faktörler: bir meta-analiz çalışması. Hacettepe Üniversitesi Eğitim Fakültesi Dergisi, 31(3), 609-627.

Sherif, V. (2018). Evaluating preexisting qualitative research data for secondary analysis. Forum: Qualitative Social Research, 19(2), 26-42.

Sirait, S. (2016). Does teacher quality affect student achievement? An empirical study in Indonesia. Journal of Education and Practice, 7(27), 34-41.

Subedi, B. R., Reese, N. ve Powell, R. (2015). Measuring teacher effectiveness through hierarchical linear models: Exploring predictors of student achievement and truancy. Journal of Education and Training Studies, $3(2), 34-43$.

Şen, Z. (2013). Türkiye'de yüksek lisans ve doktora eğitimi kalitesinin iyileştirilmesi için öneriler. Journal of Higher Education \& Science/Yüksekögretim ve Bilim Dergisi, 3(1), 10-15.

Şengül, S., Kaba, Y. ve Erdoğan, F. (2017). The analysis of middle school students' mathematical understanding in terms of different variables. Kastamonu Education Journal, 25(4), 1421-1434.

Tonbul, Y. (2017). Sosyal bilimler enstitülerinin lisansüstü eğitimin niteliğini artırmadaki rolü. Journal of Higher Education \& Science/Yüksekögretim ve Bilim Dergisi, $7(1), 150-162$.

Torres-Díaz, J. C., Duart, J. M., Gómez-Alvarado, H. F., Marín-Gutiérrez, I. ve Segarra-Faggioni, V. (2016). Internet use and academic success in university students. Comunicar, 24(48), 61-70.

Tsai, L. T. ve Yang, C. C. (2015). Hierarchical effects of school-, classroom-, and student-level factors on the science performance of eighth-grade Taiwanese students. International Journal of Science Education, 37(8), 1166-1181.

Turner, P. D. (1997, Mart, 24-28). Secondary analysis of qualitative data. Annual Meeting of the American Educational Research Association, Chicago, IL, USA. (Erişim: 02/09/2018), https://files.eric.ed.gov/fulltext/ED412231.pdf

Ural, A. ve Çınar, F. N. (2014). Anne ve babanın eğitim düzeyinin öğrencinin matematik başarısına etkisi. Mehmet Akif Ersoy Üniversitesi Eğitim Bilimleri Enstitüsü Dergisi, 3(4), 42-57.

Vandersall, K., Vruwink, M. ve LaVenia, K. N. (2011). Master's degrees and teacher effectiveness: New evidence from state assessments. Arden, NC: Arroyo. 
Visser, M., Juan, A. ve Feza, N. (2015). Home and school resources as predictors of mathematics performance in South Africa. South African Journal of Education, 35(1), 1-10.

White, M. D. ve Marsh, E. E. (2006). Content analysis: A flexible methodology. Library Trends, 55(1), 22-45.

Yavuz, O. (2018). Ergenlik döneminde internet bağımlılığının okul başarısı üzerinde etkileri. OPUS Uluslararası Toplum Araştırmalart Dergisi, 8(15), 1056-1080.

Yelgün, A. ve Karaman, İ. (2015). Düşük sosyoekonomik düzeydeki mahallede bulunan bir ilköğretim okulunda akademik başarıyı düşüren faktörler nelerdir? Eğitim ve Bilim, 40(179).

Yeşilyurt, M. E., Baştürk, R., Yeşilyurt, F. ve Kara, I. (2014). The effect of technological devices on student's academic success: Evidence from Denizli. Journal of Internet Applications \& Management/Internet Uygulamalarl ve Yönetimi Dergisi, 5(1) 39-47.

Yıldırım, H. H., Yıldırım, S., Ceylan, E. ve Yetişir, M. İ. (2013). Türkiye perspektifinden TIMSS 2011 sonuçlart. Ankara: Pelin Ofset Tipo Matbaacilık.

Zhang, D. ve Campbell, T. (2015). An examination of the impact of teacher quality and "opportunity gap" on student science achievement in China. International Journal of Science and Mathematics Education, 13(3), 489-513.

Zhou, Y. ve Wang, D. (2015). The family socioeconomic effect on extra lessons in Greater China: A comparison between Shanghai, Taiwan, Hong Kong, and Macao. The Asia-Pacific Education Researcher, 24(2), 363-377. 